\title{
A review of selected aspects of coccolithophore biology with implications for paleobiodiversity estimation
}

\author{
Jeremy R. Young ${ }^{1}$ Markus Geisen $^{2}$ Ian Probert $^{3}$ \\ ${ }^{1}$ Palaeontology Department, The Natural History Museum London \\ 2 Alfred Wegener Inst. f. Polar and Meeresforschung, Bremerhaven, Germany \\ ${ }^{3}$ Algobank-Caen, Universite de Caen Basse Normandie, Caen, France \\ email: j.young@nhm.ac.uk
}

\begin{abstract}
To help understand potential biases in coccolithophore paleo-biodiversity estimates various aspects of their biology are reviewed based on the recent monographic guide to extant coccolithophore taxonomy and research developed within the CODENET project. The evidence for life-cycles in coccolithophores involving two biomineralized phases is reviewed in detail, and it is shown that these are likely to have been pervasive through the fossil record of coccolithophores. The extent of polymorphism in extant coccolithophores is reviewed and a surprisingly strong correlation with phylogeny is documented, in particular it is shown that there is a very strong correlation between polymorphism in heterococcolith and holococcolith-bearing phases. Recent documentation of (pseudo)cryptic speciation in coccolithophores is discussed and it is argued that this provides considerable support for the rather fine morphological taxonomy adopted by nannofossil paleontologists, but also means that accurate recognition of species in the fossil record is an almost impossible goal. Finally the diversity of extant coccolithophores is compared with that recorded in Holocene sediments and it is shown that the majority of extant diversity is represented by small rare species with very low preservation potential. It is argued that this is the most serious potential biasing mechanism for study of paleobiodiversity changes since estimates of diversity at any time will be strongly influenced by the availability of well-preserved shelf sediments and of the intensity of their study by electron microscopy. Moreover, secular changes in coccolith size in relation to environmental change could significantly affect the preserved diversity of coccolithophores.
\end{abstract}

\section{INTRODUCTION}

There is considerable interest in using analysis of species diversity changes through time as an indicator of evolutionary change, particularly since such plots often show apparent correlations with major global change trends (e.g. Bown et al. 2004). Within the recently completed CODENET project (Young and Thierstein 2004) we have carried out studies of a wide range of aspects of coccolithophore biology including production of a new review of species-level taxonomy (Young et al. 2003). This work has provided various perspectives relevant to the assessment of the problems in estimating biodiversity of fossil coccolithophores. This paper reviews four main aspects of this problem: polymorphism, life-cycles, cryptic speciation and preservation potential. Our knowledge of each of these in modern coccolithophores is described in some detail and their potential impact on fossil diversity estimates are then discussed briefly. These perspectives may help inform interpretation of the patterns documented elsewhere in this volume.

\section{METHODS}

\section{Analysis of modern diversity}

For analysis of modern diversity we used the taxonomy of Young et al. (2003) A guide to extant coccolithophore taxonomy. This is by no means a perfect synthesis, but it is a useful basis for analysis, both because it is the most recent review and because it attempted to be comprehensive, including both formally described species, and many informally described morphotypes which we regarded as almost certainly genuine species.
Since it is an identification guide holococcolith and heterococcolith stages are necessarily treated separately in Young et al. (2003), and for comparison with the fossil record it is useful to do so here as well. We thus use the term coccosphere type throughout this paper to avoid the semantic problems and potential ambiguities associated with the fact that a single coccolithophore species can produce two, or perhaps more, types of coccosphere within its life cycle, and since the actual cycles have only been defined in a relatively limited number of cases. For study of extant coccolithophores the coccosphere type is the unit of identification and description and in the coccolithophore guide we described some 280 coccosphere types. For diversity analysis we created a simple database consisting of the 280 recognized coccosphere types. This database is included as available as a digital download (excel format) from the INA website (http://www.nhm.ac.uk/hosted_sites/ina//datafiles). The fields in the database are:

Species name: full taxonomic citation.

Taxonomic family: The families recognized in Young et al (2003), including the new families Alisphaeraceae and Umbellosphaeraceae and some informal groupings; narrow rimmed placoliths, narrow rimmed muroliths, nannoliths incertae sedis and holococcoliths. All these are defined in Young et al. (2003).

Coccolith length: an estimate of maximum coccolith size. We used maximum size since many coccoliths produced by extant coccoliths are so small that size is a major factor in determining whether they are preserved and can be observed in the fossil record. Under these circumstances the largest coccoliths of a species will have a significantly higher chance of being recorded in 
the fossil record. Ideally we would have used upper quartile size, but for most species only a rough estimation of normal size range is readily available and we simply used the upper end of the range. For species where data was not available from the literature we measured the maximum size of coccoliths in our micrographs.

Abundance in the plankton. Here we applied a subjective classification into four categories based on our observations and knowledge of the literature: 1 - common (i.e. occurring in high proportion of assemblages, and often at high abundances); 2 frequent (i.e. only present in a small proportion of samples, and usually at low abundances); 3 - rare (only sporadically recorded and almost never at abundances over about $1 \%$ ); very rare (only known from a few records).

Abundance in the fossil record. Here we used the same four categories plus a fifth one - never recorded.

Description date: for formally described species the date of formal description; for morphotypes which have not yet been formally described the date of first description, e.g. for Syracosphaera sp. type G of Kleijne (1993) the date is 1993.

Number of coccolith types: The number of different coccolith polymorphs present on the coccosphere, ranging from 1 (monomorphic) to 4.

\section{Schematic phylogenetic tree}

To clarify the occurrence of various characters a schematic phylogenetic tree has been constructed for the haptophytes (text-fig. 1). This is based on the tree given in Houdan et al. (2004) but with additional groups plotted on it, following the logic developed in Young and Henriksen (2003). It includes all haptophyte orders, with coccolithophores expanded to family level, following the classification of Young et al. (2003), and Jordan et al. (2004). The relationships of these groups are mainly based on molecular genetic data from the studies of Edvardsen et al. (2000), Fujiwara et al. (2001) and Saez et al. (2004). In places these molecular data have been supplemented by morphological inferences, primarily to allow groups for which there is no available molecular data to be included; these placings are indicated by dotted lines and are discussed below. It should also be noted that sampling of most families for molecular studies is very limited, so it is still possible that some families may prove to be polyphyletic. In general, however, the coccolith classification based on ultrastructure has been well-supported by the molecular data available so far (Saez et al. 2004). A more likely possibility is that some pairs of families shown as sister taxa will prove to have a paraphyletic relationship.

\section{Notes on particular points}

The coccolithophores define a single clade within the tree, and this is well-supported by molecular data. This strongly supports the inference that heterococcolith calcification evolved once only (Young et al. 1999). Within this clade the Isochrysidaceae are the main non-calcifying group and must have lost the ability to calcify secondarily, as suggested by Green et al. (1989).

The coccolithophore clade can be subdivided into a holococcolith-producing clade and non-holococcolith producing stem group. From molecular data only the Isochrysidales belong in the stem group, and this is a robust result supported by data from 18S, tufA and Rubisco genes (Edvardsen et al. 2000;
Fujiwara et al., 2001; Saez et al. 2004). However, the Ceratolithaceae and the Alisphaeraceae are known, from combination coccosphere evidence, to produce both heterococcoliths and nannoliths within their life-cycle (Alcober and Jordan 1997; Sprengel and Young 2000; Cros et al. 2000; Cros and Fortuno 2002; Young et al. 2003). Young and Henriksen (2003) argue that repeated transfer of calcification from the diploid to the haploid phase of the life-cycle is more likely than transformation of holococcoliths into nannoliths. On the basis of this argument these groups have been tentatively placed in the non-holococcolith producing stem group; i.e. we hypothesize that they evolved from an ancestor which possessed heterococcoliths in the diploid phase but was non-calcifying in the haploid phase. This hypothesis will be tested when molecular genetic data becomes available. It is of course possible that many fossil taxa fell in this stem group.

Within the holococcolith-producing clade only a very few species of the Syracosphaerales and Zygodiscales have been sequenced, and the data for their relationships relative to the Coccolithales is weak, hence the relationship is represented on the summary diagram as an unresolved polychotomy. Actually, in the molecular tree of Saez et al. (2004) the Syracosphaerales are paraphyletic and occupy a basal position in the holococcolith-producing clade. However, this is weakly supported and seems unlikely on morphological grounds, since the group produces the most complex known heterococcoliths.

There is no molecular data for the Papposphaeraceae but they are well documented as producing both holococcoliths and heterococcoliths (Thomsen et al. 1991) and so can be placed within the holococcolith producing clade. As there is no morphological evidence to associate them with any of the three orders within this clade, they are tentatively indicated as falling within the basal polychotomy. The narrow rimmed murolith grouping of Young et al. (2003) includes the genera Vexillarius, Wigwamma and Picarola. It is tentatively placed as the sister group of the Papposphaeraceae on the grounds of general similarity, they are all minute polymorphic muroliths with complex central processes, as discussed in Young et al. (2003).

The "narrow rimmed placoliths" is another tentative grouping from Young et al. (2003), including "Calyptrosphaera" sphaeroidea, Tetralithoides quadrilaminata, Placorhombus ziveriae and Turrilithus latericioides. All these have monomorphic coccospheres formed of placoliths with narrow rims and disjunct central area structures. The key species in this group is "Calyptrosphaera" sphaeroidea, which was described from the holococcolith. The heterococcolith phase has recently been described from culture observations (Noel et al. 2004). Placing this group as the sister group to the Coccolithaceae is based on molecular genetic data from the holococcolith phase, from Fujiwara et al. (2001) and Saez et al. (2004).

\section{LIFE-CYCLES}

A major outcome of recent research on coccolithophores has been the documentation of life-cycles in a sufficient number of species to allow for elucidation of a general pattern. This is important for diversity studies since in most taxa there are two separate phases producing coccoliths, with totally different ultrastructures and morphologies.

The best evidence for life-cycle changes comes from culture observations. These provide unambiguous evidence of the association of coccosphere types, and allow determination of ploidy 


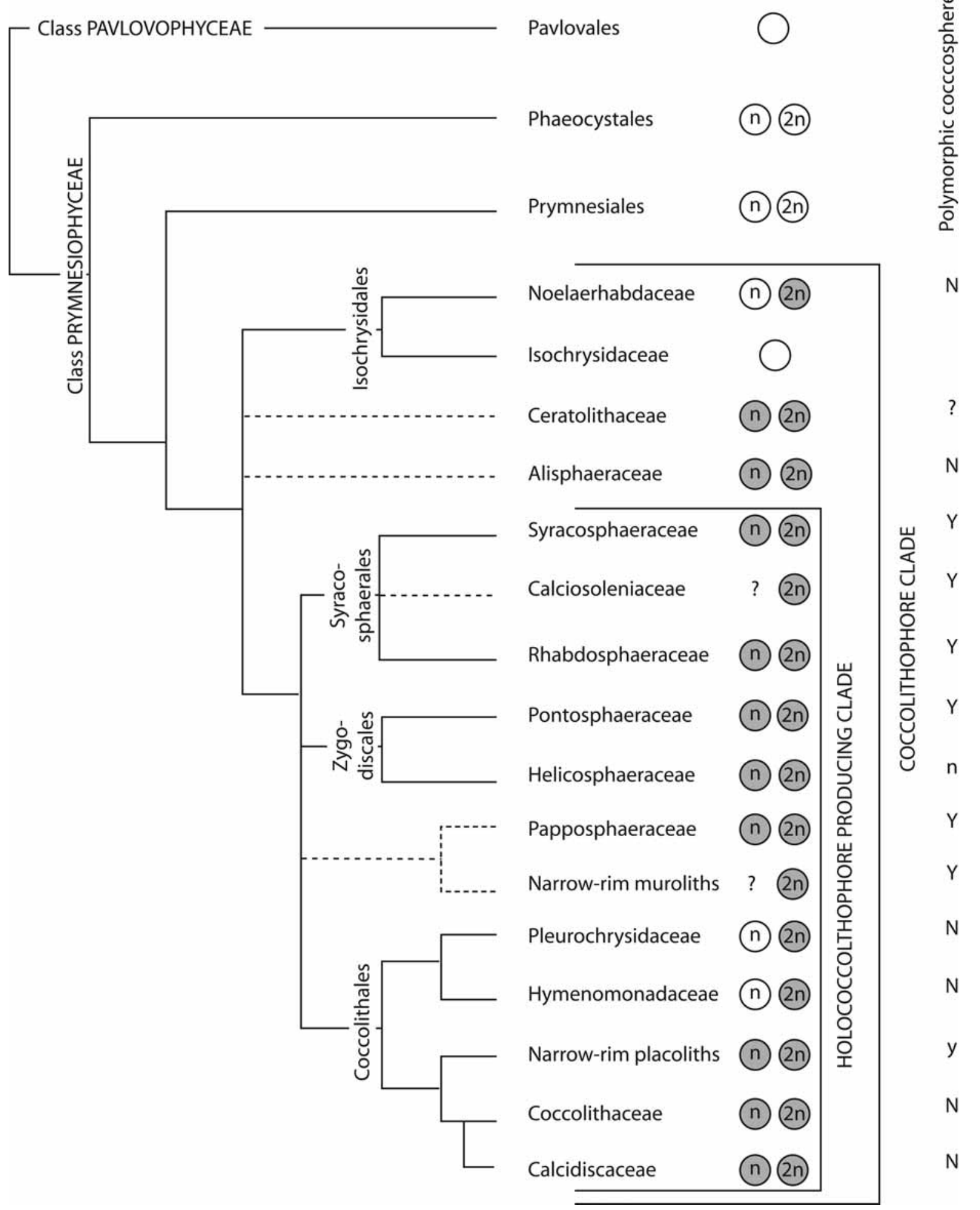

TEXT-FIGURE 1

Schematic consensus tree of relationships of extant Haptophyte families, based primarily on molecular genetic data (see text), dotted lines groups for which molecular genetic data is lacking. Shaded symbols indicate evidence of which life-cycle phases produce coccoliths ( $\mathrm{n}$ - haploid phase, $2 \mathrm{n}$ - diploid phase). Additionally the presence of polymorphic coccospheres in each group is indicated ( $\mathrm{N}$ no polymorphism, $\mathrm{n}$ - varimorphism but no true polymorphism, y - polymorphism rare in group, $\mathrm{Y}$ - polymorphism common in group).

Although haplo-diplontic life-cycles have been demonstrated from only a few percent of the species of haptophytes it is likely from the phylogenetic distribution that this is the ancestral state across the Class Prymnesiophyceae.

NB Several additional groups almost certainly fall within the coccolithophore clade, but are excluded from the figure, since there is no useful data on their affinities: Umbellosphaeraceae, narrow rimmed muroliths, Florisphaera, and Gladiolithus. Also excluded are other nannoliths which may fall outside the coccolith clade Ericiolus, and Braarudosphaera. 
levels, i.e. identification of which coccosphere types occur in the haploid phase and which in the diploid phase. Ploidy level can be determined by direct observation of syngamy or meiosis (Schwarz 1932; Gayral and Fresnel 1983), by counting of chromosomes (Rayns 1962; Fresnel 1994) or by measurement of relative DNA content using flow cytometry (Green et al. 1996; Houdan et al. 2004). Unfortunately, only a few species of oceanic coccolithophores have been cultured and in many cases life-cycle transitions have never been observed in these. It will probably be several decades before culture observations of life cycles are available for the majority of coccolithophores. In addition, however, combination coccospheres bearing coccoliths typical of two phases of the life-cycle occasionally occur and observation of these has greatly supplemented our knowledge of life cycles (e.g. Cros et al. 2000; Geisen et al. 2002).

From this work it is now clear that many haptophytes have haplo-diplontic life-cycles (Plate 1), i.e. with both the haploid and diploid phases being represented by vegetative stages, and that this is the ancestral state for coccolithophores (Billard 1994; Houdan et al. 2004; Billard and Inouye 2004). The most common pattern is for the diploid phase to produce heterococcoliths and the haploid phase holococcoliths, but the ancestral condition as represented by the basal coccolithophore group the Noelaerhabdaceae, appears to be for the haploid phase to be non-calcifying. Additionally two cases are now known of heterococcolith-nannolith life-cycle associations (Ceratolithus - "Neosphaera" and Alisphaera-"Polycrater" (Cros and Fortuño 2002). As mentioned above we predict that these nannoliths are not modified holococcoliths but separate cases of transfer of calcification from the diploid to haploid life-cycle phase. It is parsimonious to hypothesize that this is a general pattern for other nannoliths with demonstrably different biomineralisation modes from heterococcoliths; i.e. it is more likely that different biomineralisation modes have evolved as a result of repeated transfer of calcification from the diploid to the haploid phase, than by modification of diploid phase calcification. From this it follows that nannoliths with generic coccolith characteristics (composite exoskeleton, precise control of both crystallographic orientation, and crystal growth) probably are formed by haptophytes but that heterococcolith diversity provides the most useful indicator of coccolithophore diversity.

\section{Evidence for life-cycle changes}

The basic pattern of sexual life-cycles, i.e., the alternation of haploid and diploid phases via meiosis and syngamy, is common across all eukaryotes. Thus the definite occurrence of this process in even a few haptophytes is enough to prove that it must be the ancestral condition for the group, even if it may have been lost secondarily in some members. The distinctive haplo-diplontic condition, with both phases reproducing by mitosis, cannot, however, be assumed to be ancestral but may have evolved at any point within the phylogeny of the group. It is likely that the two phases were originally isomorphic with differentiation of the two phases having evolved subsequently and very possibly several times. The following notes outline the evidence for life-cycles across the taxonomy of haptophytes, the data is also summarized in text-figure 1 and the observed coccolithophore type associations in table 1 .

\section{Pavlovales}

Although numerous species have been maintained in culture for extended periods no evidence of life-cycle changes has been re- ported. Since the Pavlovales are the basal group in all molecular phylogenies it is entirely possible that they are primitively isomorphic (i.e. have identical haploid and diploid stages). It is also possible that they are secondarily asexual.

\section{Phaeocystales}

A complex life-cycle has been reported in Phaeocystis involving motile haploid flagellated cells, the well-known non-motile diploid colonial stage and diploid flagellated cells (Vaulot et al. 1994, Peperzak et al. 2000).

\section{Prymnesiales}

Although virtually all the described species are known from cultures there are very few life-cycle observations. The two exceptions are Prymnesium parvum and Chrysochromulina polylepis which have been shown to have haplo-diplontic lifecycles similar to those of coccolithophores but with both stages being motile and bearing, slightly different, scales (Edvardsen and Vaulot 1996; Larsen and Edvardsen 1998).

\section{Isochrysidaceae}

There are no life cycle observations available. Thus, we do not know if the observed phases of the various described species are diploid or haploid, or if alternate phases occur.

\section{Noelaerhabdaceae}

The life cycle of Emiliania has been very well documented and proven to be haplo-diplontic with the diploid, heterococcolith bearing, non-motile phase alternating with a haploid, scale bearing, motile phase (Klaveness 1972; Green et al. 1996; Houdan et al. 2004). An essentially identical life-cycle has also been observed in Gephyrocapsa (Probert unpublished observation).

\section{Alisphaeraceae}

Cros and Fortuno (2002) have illustrated combination coccospheres of Alisphaera with Polycrater and of Canistrolithus with Polycrater. These indicate that both heterococcolith genera alternate with a phase producing the aragonitic nannoliths of Polycrater. A parsimonious interpretation of this observation is that this life cycle is equivalent to the holococcolith heterococcolith life cycle but has evolved independently. i.e. it represents a second transition of calcification from the diploid to the haploid phase. On this basis the group can be predicted to have evolved from an ancestor without haploid phase calcification, and thus from outside the holococcolith producing clade. Obviously this hypothesis needs to be tested by molecular genetics, but provides a basis for the tentative placement of this group shown in the schematic phylogeny.

\section{Ceratolithaceae}

Ceratolithus has never been cultured but is known to form three coccosphere types. (1) Non-motile cells surrounded by a single horseshoe-shaped ceratolith, which were described by Norris (1965). (2) Similar cells occurring within a much larger coccosphere of hoop-shaped coccoliths, also described by Norris (1965), and frequently observed since. Up to four cells may occur within the coccosphere. (3) Non-motile cells enclosed by a normal coccosphere of imbricating planolith coccoliths. These were formerly regarded as a separate species, Neosphaera coccolithomorpha but combination cells of hoop coccoliths and planoliths, and even of hoop coccoliths, planoliths and ceratoliths have been observed (Alcober and Jordan, 1997; Young et al. 1998; Sprengel and Young 2000). As 


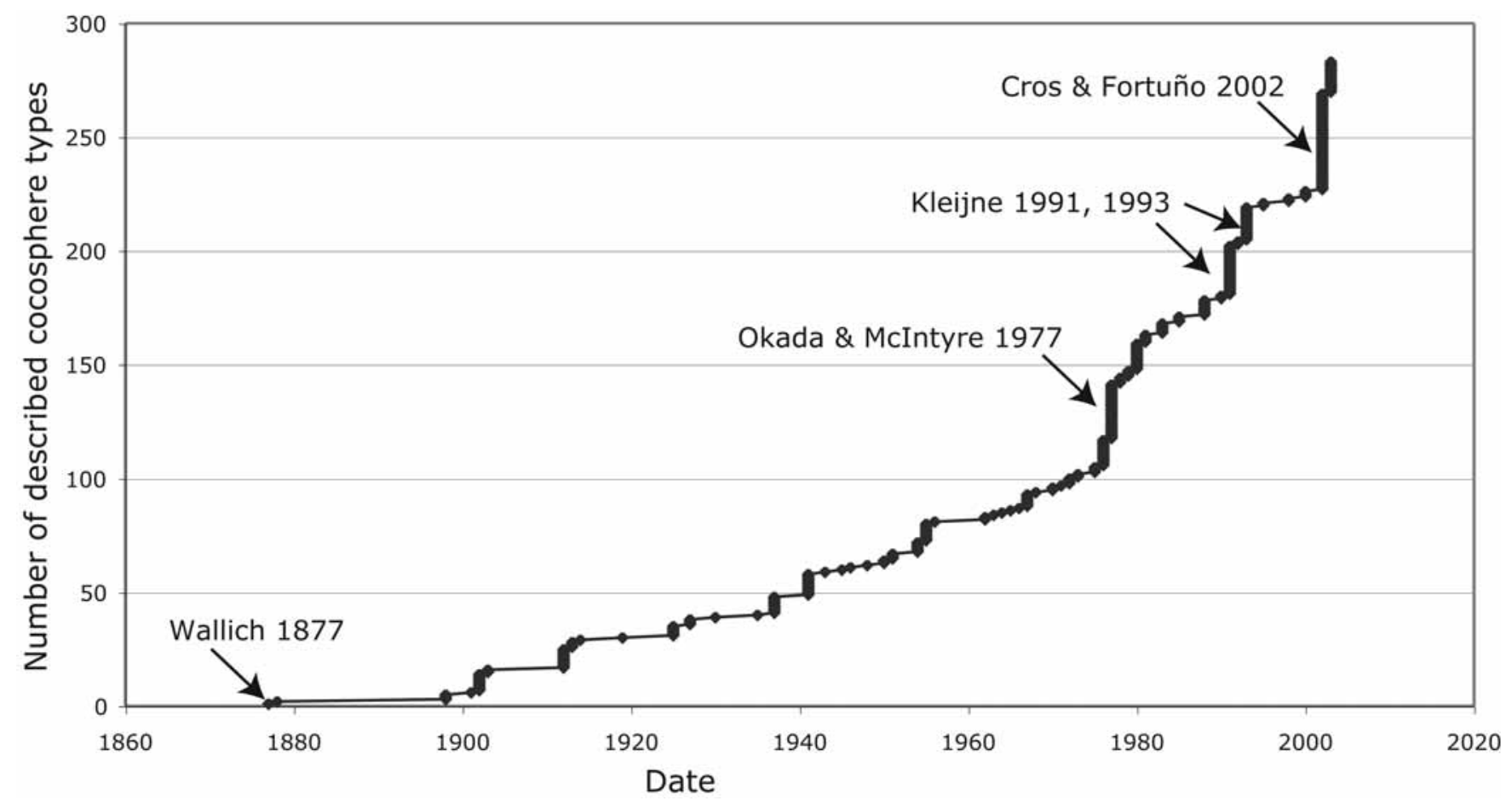

TEXT-FIGURE 2

Increase in number of described coccosphere types through time. The plot is based on the date of description of the 280 coccosphere types recognized in Young et al. (2003), various key studies are indicated. The plot includes informally described species with date of first description (e.g. Syracosphaera sp. type $\mathrm{G}$ of Kleijne 1993) and holococcolithophores. The absence of any evidence of a plateau in the data is rather striking.

with the Alisphaeraceae the hypothesis of independent origin of calcification in the haploid phase allows tentative placement in the phylogenetic tree. In this case, however, the placement is even more tentative since there is no reported motile stage and for syngamy to occur the haploid phase must be motile during at least part of the life cycle. Thus if the ceratolith-bearing phase is haploid there must be an additional motile, gamete stage. This is not impossible: for instance, in Pleurochrysis, the haploid phase of the life cycle can include both non-motile benthic stages and motile, planktonic, gametes (e.g., Gayral and Fresnel 1983).

\section{Syracosphaeraceae}

Eleven of the fifty two heterococcolith-based species have been shown to form combination coccospheres with holococcolith "species" (Cros et al. 2000; Cros and Fortuno 2002; Triantaphyllou et al. 2003). In addition two of these life-cycle associations (Syracosphaera pulchra and Coronosphaera mediterranea) have been substantiated by culture observations (Geisen et al. 2002) and their ploidy levels determined (Houdan et al. 2004).

\section{Rhabdosphaeraceae}

Three of the twenty one heterococcolith-based species have been shown to form combination coccospheres with holococcolith species (Cros et al. 2000; Triantaphyllou et al. 2003). None of these have yet been definitively proven by culture observations.

\section{Helicosphaeraceae}

Definite combination coccospheres have been documented for $H$. carteri by Cros et al. (2000) and a possible one for $H$. wallichii by Geisen et al. (2004). No culture transitions have been observed despite several cultures having been maintained for several years.

\section{Pontosphaeraceae}

No combination coccosphere or culture life cycle observations are yet available. Since the family definitely falls within the holococcolith-producing clade we might expect that the haploid phase will prove to be holococcolith-bearing. It is, however, curious that there are no obvious candidate holococcolithophores, we would expect these to produce large coccospheres with holococcoliths structurally similar to those of Helicosphaera. As there are no obvious candidates, it is conceivable that holococcolith calcification has been lost in this group.

\section{Papposphaeraceae}

Eleven of the twenty one heterococcolith-based species have been shown to form combination coccospheres with holococcolith species (Thomsen et al 1991). None of the species have been cultured.

\section{Narrow-rimmed muroliths}

One of the seven species included in this tentative grouping, Wigwamma annulifera, has been shown, to form combination coccospheres with holococcoliths (Thomsen et al. 1991).

\section{Pleurochrysidaceae}

Three of the seven heterococcolith-based species have been observed in culture to alternate with non-calcifying, scale-bearing, phases. Both phases are motile and ploidy levels have been determined by chromosome counts and observations of syngamy 
(Gayral and Fresnel 1983; Rayns 1962). Since this family falls within the holococcolith-producing clade the absence of holococcoliths in the haploid phase must be due to secondary loss.

\section{Hymenomonadaceae}

Two of the five heterococcolith-based species have been observed in culture to alternate with non-calcifying, scale-bearing phases. Both phases are motile and ploidy levels have been determined by chromosome counts and observations of syngamy (Fresnel 1994, Schwarz 1932). As with the Pleurochrysidaceae the absence of holococcoliths in the haploid phase must be due to secondary loss.

\section{Narrow rimmed placoliths}

One of the five species included in this tentative grouping, "Calyptrosphaera" sphaeroidea, has been shown, by culture observations, to have alternate heterococcolith-bearing and holococcolith-bearing phases (Noel et al. 2004). According to Saez et al. (2004) several poorly characterized holococcolith cultures, including Calyptrosphaera radiata (Sym and Kawachi 2000) plot in molecular genetic analyses close to $C$. sphaeroidea and so they may represent holococcolith phases of this group.

\section{Coccolithaceae}

Parke and Adams (1960) showed that Coccolithus pelagicus has a life-cycle involving alternation of holococcolith- and heterococcolith-bearing phases. This result was entirely unexpected at the time but it has been amply confirmed since (Rowson et al. 1986). Both phases are common in the water column and with the advent of systematic SEM studies several combination coccospheres have been recognized in plankton samples (e.g. Samtleben and Bickert 1990; Geisen et al. 2002). The hypothesis that the holococcolith phase is haploid and the heterococcolith phase diploid was tentatively suggested by Parke and Adams (1960), strongly suggested by Billard (1994) and has now been proven by ploidy level determination using flow cytometry (Houdan et al. 2004). The other extant genus in this family, Cruciplacolithus, is represented by one species $C$. neohelis, it has never been observed to form an alternate life cycle phase despite being maintained in culture for several decades.

\section{Calcidiscaceae}

This family includes two extant genera, Calcidiscus and Umbilicosphaera. Three species are now recognized in Calcidiscus, although only two of these have been formally described (Saez et al 2003; Quinn et al. 2004), both of which have well-documented holococcolith phases based on observations of combination coccospheres (Kleijne 1991; Cortes 2000; Renaud and Klaas 2001; Geisen et al. 2002) and in the case of C. leptoporus culture observations (Geisen et al. 2002; Houdan et al 2004). None of the four Umbilicosphaera species have yet been shown to have holococcolith phases.

\section{Phylogenentic implications of life-cycle results}

As outlined above haplo-diplontic life-cycles have been demonstrated across the diversity of the Prymnesiophyceae, moreover life-cycle type has been shown to be a highly conservative feature in phytoplankton (Valéro et al. 1992; Houdan et al. 2004). Thus, from basic cladistic logic, this should be a synapomorphy of the group, i.e., the ancestral condition for the clade that would characterize all members of the clade unless it has been lost secondarily, which should only be inferred on the basis of definite evidence. The haplo-diplontic life cycle with two independent asexually reproducing stages is unusual and is likely to be a key ecological adaptation of the Prymnesiophyceae, allowing the two phases to exploit discrete ecological niches and so survive in unstable environments (Houdan et al. 2004; Noel et al. 2004). A significant consequence of this is that we can reasonably infer that important aspects of the basic ecological adaptation of coccolithophores are inherited from their non-calcifying ancestors and therefore that coccolithophores are likely to have had broadly similar ecological adaptations through their geological record, rather than having drastically changed their adaptation in response to a changing environment, or for instance evolution of the diatoms.

Hence we should predict that all coccolithophores will have haplo-diplontic life cycles. We can also reasonably predict from the available data that heterococcoliths are always produced during the diploid phase of the life cycle, with the haploid phase being either non-calcifying or having a different calcification mode. Holococcolith calcification is the most common biomineralization-mode in the haploid phase of extant coccolithophores and must have been throughout the Cenozoic, since the holococcolith producing families can be traced back to at least the Paleocene. Holococcoliths are also present in the fossil record down to at least the upper Toarcian (185 Ma) as shown by Bown (1993). However, we cannot infer holococcolith calcification for extinct families (e.g. Podorhabdaceae, Watznaueriaceae) for which we have no reliable data on their phylogenetic relationships to the holococcolith-producing clade. Such groups may equally probably have had a non-calcifying haploid phase since this is likely to be the ancestral condition for the coccolithophores as a whole, or in at least some cases to have produced nannoliths. Following from this the approach of Bown et al. (2004) of analysing heterococcolith diversity separately from holococcoliths and nannoliths is clearly sensible.

\section{POLYMORPHISM}

Many modern coccosphere types are polymorphic, i.e. have two or more coccolith types on a single coccosphere. This does not present any problems for assessing modern biodiversity, indeed polymorphism increases the amount of morphological data available for analysis and so is a very useful taxonomic feature. However, it obviously is a problem for assessment of fossil biodiversity since the fossil record is predominantly composed of isolated coccoliths.

\section{Polymorphism in motile taxa}

There is a strong association of polymorphism with motility, most motile coccolithophores produce polymorphic coccospheres (plates 2, 3), whilst most non-motile coccolithophores produce monomorphic coccospheres. This is almost certainly a functional effect, motility usually results in a well-defined flagellar opening both in the coccosphere and in the underlying cell wall (see pl. 2, fig. 2b). Differentiation of coccoliths around this opening is very common and appears to be directed toward protecting this area. In many cases the circum-flagellar coccoliths are smaller and/or more angular than the body coccoliths thus allowing closer coverage of the circum-flagellar area (e.g., Michaelsarsia [pl. 2, fig 3], Syracosphaera pirus). In Helicosphaera (pl. 3, fig. 1) the circum-flagellar coccoliths are larger and have better developed wings than the body 

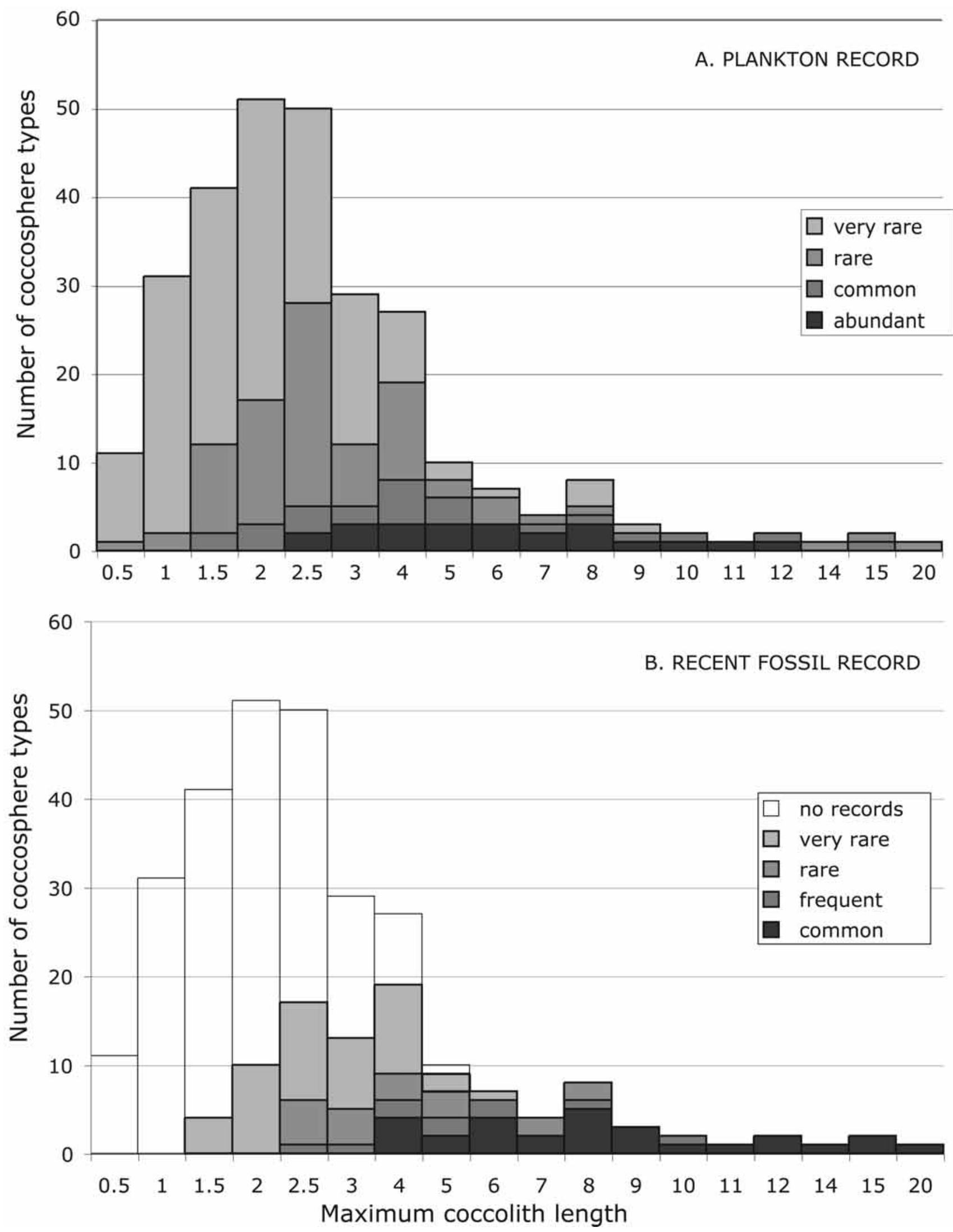

TEXT-FIGURE 3

Size frequency histograms for modern coccolith species as observed respectively in the modern plankton and in the fossil record. Shading indicates subjective assessment of abundance (see methods). The large number of rare coccolithophore types producing small coccoliths is the basic reason for the fossil diversity being much lower than the modern diversity. 
coccoliths, but again the effect is to protect the flagellar opening. Even more commonly the circum-flagellar coccoliths have taller spines or processes than the body coccoliths. This is seen for instance in most Syracosphaeraceae and good examples of this are also seen in the Papposphaeraceae and Rhabdosphaeraeceae (e.g. Algirosphaera, Acanthoica, pl. 3, fig. 2). This is essentially the only type of dimorphism shown by holococcolithophores, and occurs in about half of them, most commonly with a flattened transverse process being developed (helladolith morphology).

Motility also often results in coccospheres developing asymmetrical shapes, with test elongation in the direction of swimming, resulting in pear-shaped or cylindrical coccospheres. In these coccospheres there is frequently more or less continuous variation in coccolith size and/or shape along the coccosphere (varimorphism). In addition the antapical coccoliths are often distinctly different from the body coccoliths. As with circumflagellar coccoliths the antapical coccoliths may differ in size or shape, or develop spines. Antapical coccolith differentiation is seen in some species of several different groups of coccolithophores, including the Rhabdosphaeraceae (pl. 3, fig. 2), Calciosoleniaceae, Syracosphaeraceae (pl. 2, fig. 1) and Papposphaeraceae. As with circum-flagellar coccolith differentiation it is almost certainly a functional adaptation that has evolved repeatedly.

The strongest form of polymorphism is dithecatism (pl. 2, figs. 1,2 ), i.e., the formation of a discrete outer layer (exotheca) of coccoliths with different morphology than the body coccoliths of the endotheca. This occurs exclusively in the Syracosphaeraceae, although with a very wide range of exothecal coccolith morphologies (Cros 2000; Cros and Fortuno 2002; Young et al. 2003). It is clear that exothecal coccoliths are modified endothecal coccoliths (Inouye and Pienaar 1988; Young et al. 2004) although in some cases the structures have become so modified that this is only apparent from comparison of a range of exothecal morphologies. For instance the exothecal coccoliths of Syracosphaera anthos appear completely different from the body coccoliths but exothecal coccoliths with intermediate degrees of differentiation occur in S. nodosa and S. bannockii. Given the wide range of exothecal coccolith morphologies in contrast to a rather low range of body coccolith morphologies in Syracosphaera a possible explanation is that exotheca have been evolved relatively recently and resulted in a radiative evolution of the genus. This hypothesis is potentially testable by molecular genetic study of divergence times in the group (cf. Saez et al. 2003).

Exotheca formation is less obviously related to motility than the other forms of polymorphism discussed so far, but in many species the exotheca is usually incomplete and concentrated at the flagellar pole of the coccolith (e.g. S. molischii, S. ossa). Moreover it is difficult to envisage how coccoliths could be arranged in an exotheca without the possibility of them being exocytosed at the flagellar pole and arranged by the flagella. Finally it should be noted that other Syracosphaeraceae, Michaelsarsia and Calciopappus have circum-flagellar appendages formed of highly modified coccoliths that are possibly homologous with the exothecal coccoliths in Syracosphaera.

\section{Polymorphism in non-motile coccolithophores}

Whilst most non-motile coccolithophores are monomorphic (including all Coccolithaceae, Calcidiscaeae and Noelaerhabdaceae) there are some exceptions. The most significant are
Rhabdosphaera, Umbellosphaera and Scyphosphaera (plate 4). In Rhabdosphaera the coccosphere consists of approximately equal numbers of spine-bearing and non spine-bearing coccoliths which are dispersed around the coccosphere. In Scyphosphaera the characteristic bowl-shaped coccoliths (lopadoliths) only occur in an "equatorial" ring whilst the rest of the coccosphere is covered by very low rimmed-muroliths. In Umbellosphaera there is typically a wide range of coccolith sizes on a single coccosphere but with a broad tendency toward a division into macrococcoliths with broad rims and micrococcoliths with narrow rims, which usually are not seen on the outer surface of the coccosphere. Actually Scyphosphaera coccospheres are not absolutely non-motile since flagella have been observed both in culture (Probert unpublished observations) and in natural populations (e.g. Lohmann 1902). However, most cells do not have flagella. Similarly there are records of motile Umbellosphaera cells (Markali and Paasche 1955). There are no records of motile Rhabdosphaera cells (and many observations of non-motile cells) and the two coccolith types are distributed across the coccosphere, but the genus does belong to the Rhabdosphaeraceae, a family with many motile genera.

\section{Distribution of polymorphism in modern nannoplankton}

The distribution of polymorphism across coccolithophore phylogeny is shown in text-figure 1. Polymorphism does not unambiguously define a clade but is strongly concentrated in particular families, especially the Syracosphaeracaea (54 out of 55 species are polymorphic), Rhabdosphaeraceae (12 out of 20) and Papposphaeraceae ( 8 out of 22). The Syracosphaeraceae and Rhabdosphaeraceae are almost certainly closely related and the Papposphaeraceae conceivably fall in the same clade so polymorphism in these three groups may have a common origin. By contrast there is no polymorphism in the Noelaerhabdaceae, Alisphaeraeaceae, Pleurochrysidaceae, Hymenomonadaceae, Coccolithaceae or Calcidiscaceae and only varimorphism in the Helicosphaeraceae. Scyphosphaera apsteinii, the single polymorphic species in the Pontosphaeraceae is an obvious anomaly and appears to be a clear case of separate evolution of polymorphism.

In addition 51 of the 86 holococcolith-bearing coccosphere types are dimorphic and among life-cycle associations identified to date there is a strong association of polymorphism in the heterococcolith phase with polymorphism in holococcolith phase (table 1). Considering only heterococcolith-holococcolith associations of the 30 identified associations, 6 examples are unambiguous of monomorphic heterococcolith and holococcolith phases, e.g. Calcidiscus quadriperforatus (plate 1). There are a further 18 examples of either dimorphic or polymorphic heterococcolith phases being associated with dimorphic holococcolith phases, e.g. Coronosphaera mediterranea with Calyptrolithina wettsteinii. Three examples involve association of a varimorphic phase with a monomorphic phase (Helicosphaera carteri, H. wallichii and Papposphaera borealis). As argued above varimorphism is probably functionally equivalent to polymorphism, since in both cases the coccolith morphology varies according to location on the coccosphere. However, in the case of varimorphism there is no structural differentiation of the coccoliths, so probably in terms of the coccolith formation process this is better seen as modified monomorphism. Of the remaining three associations, two cases (Quaternariella obscura and Calciarcus cf. alaskensis) are too poorly documented to allow judgement. Finally Syracosphaera anthos provides the single unambiguous case of an association of a 


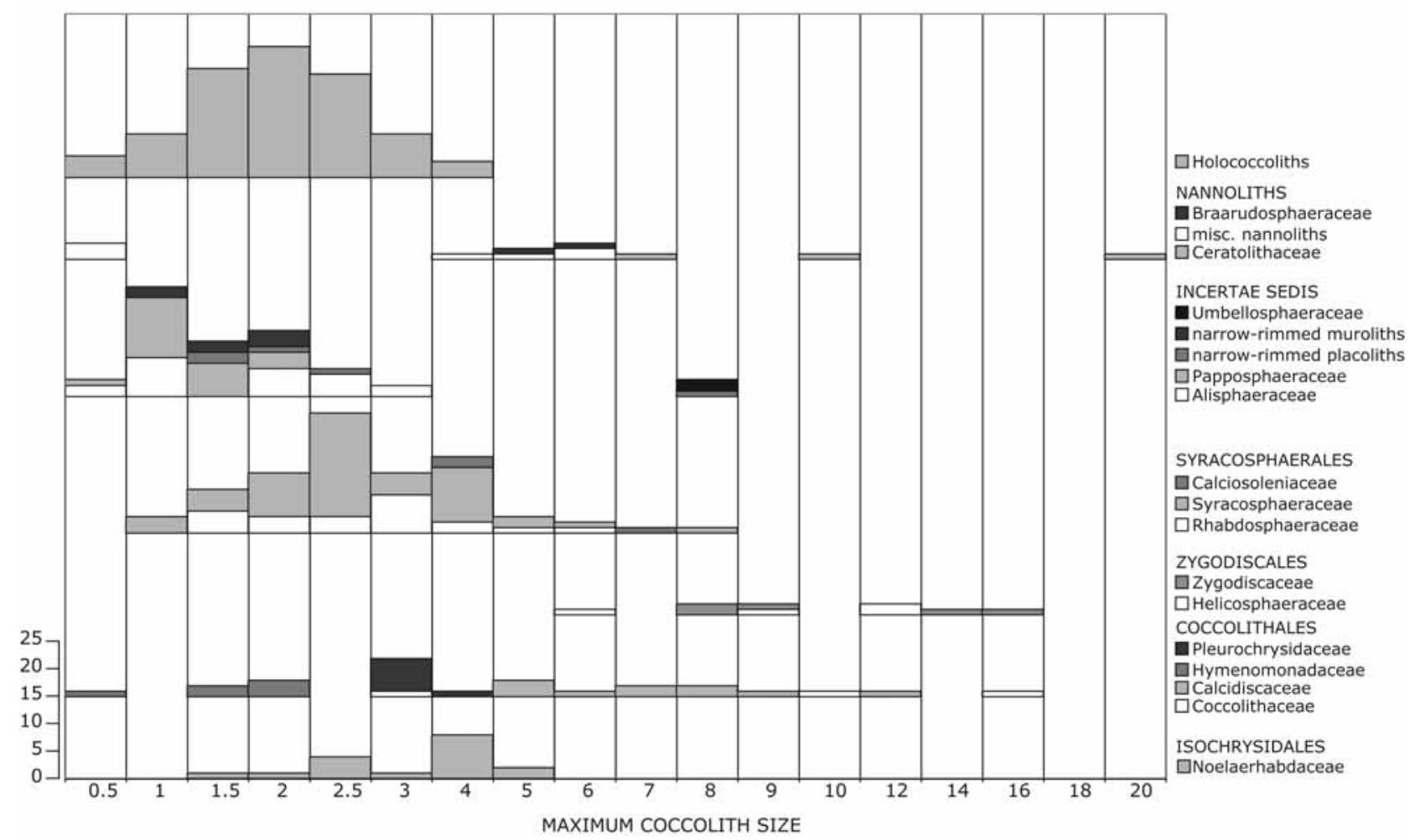

TEXT-FIGURE 4

Size frequency plots of extant coccoliths by taxonomic group. The large number of coccosphere types with small coccoliths is predominantly composed of holococcolithophores, the incertae sedis families and Syracosphaerales, and consequently these groups have very incomplete fossil records.

polymorphic phase with a monomorphic phase. In this case the heterococcolith stage is strongly polymorphic with well-differentiated body coccoliths, circum-flagellar coccoliths and exothecal coccoliths (pl. 2, fig. 2a). By contrast the holococcolith phase ("Periphyllophora mirabilis") is monomorphic (pl. 2, fig. 2b).

The same pattern arguably holds with the associations involving heterococcoliths and nannoliths. The Alisphaera and Canistrolithus associations with Polycrater are monomorphicmonomorphic associations. In Alisphaera there is often significant variation in coccolith form on the cell but this is not consistently related to position on the cell. Ceratolithus is more ambiguous, the planolith-bearing ("Neosphaera") phase being clearly monomorphic such as the cells with only ceratoliths. However, the rather common coccospheres of hoop-coccoliths with ceratolith-bearing cells inside are clearly dimorphic, but possibly these are a type of transitional combination coccosphere. So it is unclear whether this should be regarded as an association of three different monomorphic phases or of a monomorphic and dimorphic phase.

In summary of the 34 associations, there is a clear correlation of presence/absence of definite polymorphism between the phases in 29 associations, 2 ambiguously complex cases (Ceratolithus), 2 cases with inadequate data and only one clear exception (Syracosphaera anthos). This is far higher than could be expected by coincidence and indicates that presence/absence of polymorphism in holococcolithophore stages can be an important clue to affinities.
The strong association of polymorphism with particular families and the correlation of polymorphism in the heterococcolith phase with polymorphism in the holococcolith phase both suggest that evolution of polymorphism probably involves complex modification of the biomineralisation process and may not have occurred often in the evolutionary record. Following this we can predict that polymorphism in extant coccolithophores is a good guide to polymorphism in their ancestors. So for the Cenozoic coccolithophores we can be reasonably confident that polymorphism was essentially confined to the Syracosphaeraceae, Rhabdosphaeraceae, Papposphaeraceae and the genus Scyphosphaera. For extinct Cenozoic nannolith groups and the numerous Mesozoic coccolithophore families with no clear modern descendants judging the possible extent of polymorphism is much more difficult. The obvious way to determine polymorphism in the fossil record is from observation of coccospheres. Whilst the overwhelming majority of coccoliths are disassociated, a few coccospheres can be found in most fossil samples (e.g. Young et al. 1986, Mai et al. 1997). Unfortunately, however, these coccospheres are predominantly non-motile monomorphic placolith-bearing genera such as Coccolithus, Gephyrocapsa, Reticulofenestra, Chiasmolithus, or Watznaueria. These coccospheres have tightly interlocked coccoliths and thus may survive even in fecal pellets. The motile polymorphic genera such as Syracosphaera or Acanthoica, and all of the holococcolithophores, have coccospheres in which the coccoliths are much less tightly interlocked and which are much less commonly preserved as coccospheres. There is potential for such coccospheres to occasionally survive sedimentation if they are entrained in flocs of marine snow but they would then nor- 
mally be destroyed during bioturbation. Consequently the key source of data has to be laminated anoxic sediments with good calcite preservation. Such sediments are rare since calcite preservation is usually poor in anoxic sediments, but several examples have been documented (e.g., Covington 1985, Lambert 19861987 1993). Polymorphic coccospheres have been identified in such sediments and may be used as clues to assess which extinct families are likely to have shown polymorphism.

\section{(PSEUDO-)CRYPTIC SPECIATION}

A major limit on our ability to assess total biodiversity is our ability to discriminate species. In the case of coccolithophores there has historically been uncertainty as to whether fine-scale morphological variants represent genotypically discrete species or ecophenotypic morphovariants produced in response to varying ecological conditions. Evidence from morphometric work and biostratigraphic experience has tended to favour the former hypothesis (e.g., studies of Knappertsbusch et al. 1997; Bollmann 1997). However, it is difficult to draw definitive conclusions from single lines of evidence. Thus the CODENET project adopted a multi-disciplinary approach combining data from molecular genetics, culture experiments, morphometric study of a range of samples and fine-scale qualitative examination of morphology (Geisen et al. 2004). Culture work is particularly valuable since it allows direct testing of hypotheses derived from field studies. The species Calcidiscus leptoporus (sensu lato) exemplifies this well and has been particularly thoroughly studied. It shows a wide range of size variation in the field with three intergradational morphotypes being widely recognized - small (coccoliths 3-5 microns), intermediate (5-8 microns) and large (8-10 microns), as first suggested by Kleijne (1993) (see plate 5). Knappertsbusch et al. (1997) studied these extensively using both plankton and geological samples and concluded that they represented discrete populations, but were unsure whether they should be regarded as discrete species or ecologically-controlled intra-specific variants. Culture experiments (Steel 2000; Quinn et al. 2003 2004) subsequently demonstrated that coccolith size was a relatively stable feature in culture. Ecological conditions such as temperature and nutrient levels do affect coccolith size but to a much smaller degree than the main morphotype variation. This conclusion is reinforced by evidence from life-cycle associations (Geisen et al. 2002), the large morphotype of $C$. leptoporus producing very different holococcoliths in the haploid phase compared to the intermediate morphotype (indeed the holococcoliths were previously placed in different genera - Crystallolithus rigidus and Syracolithus quadriperforatus). Finally this was definitively proven by molecular genetics (Saez et al. 2003). The large and intermediate morphotypes proved to be well-separated species using both $18 \mathrm{~S}$ rDNA and the chloroplast gene tufA Clearly multiple lines of evidence lead to the same conclusion, that the different morphotypes are in fact discrete species. Following this, Saez et al. (2003) proposed the new combination Calcidiscus leptoporus ssp. quadriperforatus for the large form, subsequently modified to Calcidiscus quadriperforatus by Quinn et al. (2004).

There are also, however a couple of informative complications in the Calcidiscus case study. First, the small morphotype has not yet been successfully cultured. Thus there is no molecular genetic data or direct culture data on morphological stability of this morphotype, nor has its holococcolith stage been identified. Nonetheless, we can rather strongly predict that it will prove to be a discrete species, since it is at least as different morphologically from the intermediate form as the intermediate form is from the large form (e.g., Quinn et al. 2004). This is supported by the observation that in culture experiments the intermediate form produced very few coccoliths in the size range of the small form and no culture conditions resulted in an assemblage of coccoliths with a mean size below $5 \mu \mathrm{m}$ (Steel 2001; Quinn et al. 2003, 2004). The combination of methods also allows results to be extrapolated to cases where fewer lines of evidence are available.

Second, the large morphotype can be distinguished not only by size but also by the presence of a zone of obscured sutures on the distal shield around the central area (Baumann and Sprengel 2000). This character was overlooked by many workers, including Knappertsbusch (1997), since it looks rather like a result of corrosion or malformation. However culture observations (Steel 2001; Quinn et al. 2004) proved that it was consistently present in certain cultures and indeed showed a more reliable correlation with species identity, as indicated by molecular genetic results than mean coccolith size. The intermediate form $(C$. leptoporus sensu stricto) produces coccoliths ranging in size from 5 to $8 \mu \mathrm{m}$ but never shows the zone of obscured sutures, whilst the large morphotype ( $C$. quadriperforatus) produces coccoliths ranging in size from 6 to $10 \mu \mathrm{m}$, but virtually always showing the zone of obscured sutures. Indeed some of the $C$. quadriperforatus cultures, as identified by both suture characteristics and molecular genetics, consistently produce coccoliths falling within the size range of $C$. leptoporus sensu stricto. Interestingly these anomalous small $C$. quadriperforatus cultures can also be distinguished from normal-sized $C$. quadriperforatus cultures by molecular genetics, due to slight differentiation in the tufA gene (Saez et al. 2003). Thus it seems likely that $C$. quadriperforatus itself is composed of two recently diverged populations, arguably species. Hence, the pattern of Calcidiscus leptoporus sensu lato consisting of three discrete deeply diverged species is almost certainly an oversimplification, with additional finer scale differentiation occurring.

\section{PLATE 1}

The typical coccolithophore life-cycle.

Summary of the typical coccolithophore life-cycle, illustrated by Calcidiscus quadriperforatus. The dominant reproduction process is mitosis (asexual binary division) which occurs in both the haploid and diploid phases. Transitions between the phases through meiosis or syngamy occur only rarely but occasionally are captured by observation of combination coccospheres.

The illustrated combination coccosphere has a heterococcolith-bearing, and so diploid, cell emerging from inside a covering of holococcoliths inherited from fusion of two haploid cells during syngamy. 


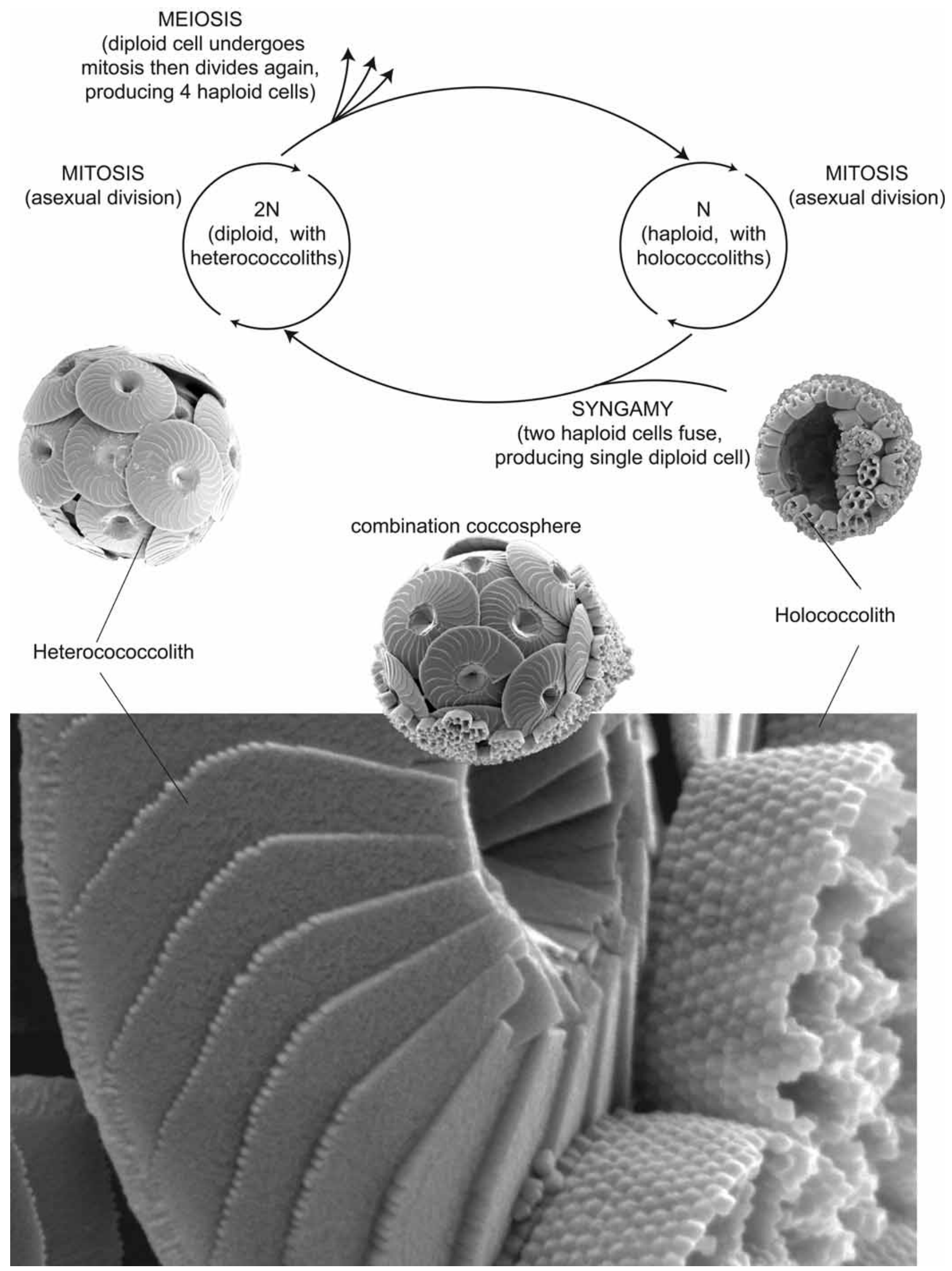


Calcidiscus leptoporus is the best documented case of pseudocryptic variation among coccolithophores, but study of other species has revealed that this is a common pattern. Coccolithus pelagicus certainly includes two genotypically discrete species or sub-species (Geisen et al. 2002; Saez et al. 2003; Geisen et al. 2004) and probably at least three (Parente et al. 2004). Gephyrocapsa oceanica probably comprises two discrete morphotypes and G. muellerae three (Bollmann et al 1997; Bollmann et al. 2002). Helicosphaera carteri, H. wallichii and $H$. hyalina which had been suggested by some authors to be intergradational morphotypes (Nishida 1979; Jordan and Young 1990) have proven to be well differentiated species (Saez et al. 2003; Geisen et al. 2004). Similarly, Umbilicosphaera sibogae var. foliosa and U. sibogae var. sibogae which had been suggested to be ecophenotypes or even life-cycle stages (Inouye and Pienaar 1984) have been shown to be very well differentiated species (Saez et al. 2003; Geisen et al. 2004). Emiliania huxleyi consists of at last three genotypically distinct types or species (Young and Westbroek 1991; Bleiswijk et al. 2001; Medlin et al. 1996) and probably at least five (Findlay and Giraudeau 2000; Paasche et al 2002; Iglesias-Rodriguez et al. 2002; Young et al. 2003).

The preceding examples are all cases where relatively subtle morphological variation has proven to be indicative of genetic differentiation and so examples of pseudo-cryptic rather than cryptic-speciation. By contrast, the species Syracosphaera pulchra and Coronosphaera mediterranea have been regarded as very well-defined and as showing rather little variation. However, in both these species life-cycle evidence from both combination coccospheres and culture studies suggests that they in fact include respectively at least two ( $S$. pulchra) and three (C. mediterranea) species which show obvious morphological differentiation in the haploid (holococcolith-producing phase), but no obvious differentiation in the diploid (heterococcolith-producing phase) (Geisen et al. 2002; Saugestad and Heimdal 2002; Houdan et al 2004; Geisen et al. 2004).
It is dangerous to extrapolate from case studies to general rules but it is hard to escape the conclusion that conventional species concepts for modern coccolithophores are generally conservative. So it is very likely that further molecular genetic, fine morphological and culture-based research will reveal numerous further cases of cryptic and pseudo-cryptic variation and that this will significantly increase the number of species. Obvious examples of biogeographically widespread species with high degrees of morphological variation include Florisphaera profunda, Umbellosphaera tenuis, Syracosphaera molischii, Algirosphaera robusta, and Ophiaster hydroideus, notes on all these are given in Young et al. (2003). Studies of other planktonic micro-organisms are similarly showing parallel evidence for cryptic and pseudocryptic variation (reviewed in de Vargas et al. 2004).

For interpretation of paleontological data this recognition of fine scale diversity in the plankton provides considerable validation for the rather fine species concepts adopted by biostratigraphers, including the increasingly widespread use of size-defined taxa. It also makes it unlikely that artificial splitting of continuous phylogenetic lineages is as widespread a problem as has been suggested (e.g. Young et al. 1994). Nonetheless there are many fossil taxa which in the light of results from the modern coccolithophore flora appear implausibly wide-ranging and morphologically variable.

\section{TOTAL BIODIVERSITY AND PRESERVATION IN THE FOSSIL RECORD}

\section{Diversity of modern coccolithophores}

The most commonly cited estimate for the number of extant coccolithophores is ca. 200, based on the taxonomic syntheses of Jordan and co-workers (Jordan and Kleijne 1994; Jordan and Green 1994; Jordan and Chamberlain 1997; Jordan et al. 2000). However, this estimate includes about 60 holococcolithophores which arguably should be eliminated since they likely represent

\section{PLATE 2 \\ Polymorphism in the Syracosphaeraceae}

1 Syracosphaera sp. type G of Kleijne 1993 showing a complex range of coccolith types. In the upper half of the specimen there are numerous body coccoliths with stubby spines and proximal flanges. Around the flagellar opening a few circum flagellar coccoliths with long spines are present. Above these are a few exothecal coccoliths which in this species are only weakly differentiated from the body coccoliths; the wall is higher and the flange is reduced to a beaded rim. In the lower part of the coccosphere the body coccoliths show varimorphism with reduction in spine development. At the base of the coccosphere four antapical coccoliths occur, distinguished by development of spikes growing out from the rim.

2a Syracosphaera anthos heterococcolith phase, coccosphere showing an almost complete exotheca of very strongly modified coccoliths, inside this one spine-bearing circum flagellar coccolith and a few body coccoliths are visible.

2b Syracosphaera anthos holococcolith phase (formerly "Periphyllophora mirabilis"), this is monomorphic, all coccoliths are helladoliths. The association of a polymorphic heterococcolithophore and monomorphic holococcolithophore is very unusual (see text).

3,4 Michaelsarsia elegans, showing monomorphic body coccoliths, lenticular circum-flagellar coccoliths with short spines and a ring of whorl coccoliths supporting arms formed of chains of highly modified coccoliths "osteoliths". 


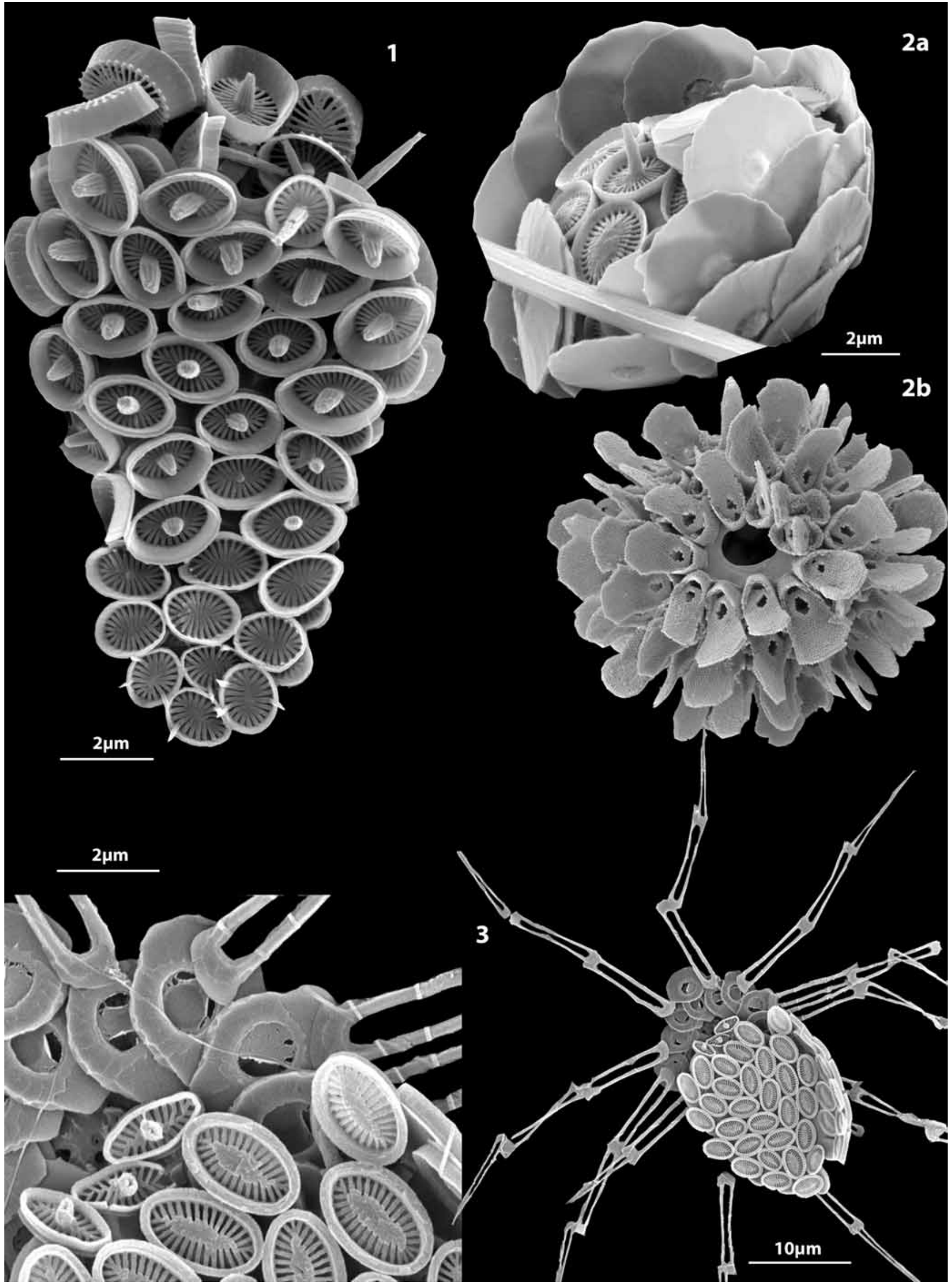


the life-cycle phases of heterococcolithophores. Diversity thus can be reduced ca. 140 species. Conversely the compilations of Jordan and co-workers were based only on formally described species, excluding the rather large number of well-established but only informally described species (there are collaborative efforts under way to describe these but they have progressed rather slowly). Many of these were described by Kleijne (1991 1993) but many more have recently been recognized through the work of, in particular, Cros and Fortuno (2002). These informally recognized taxa were included in Young et al. (2003), leading to the substantially higher estimate of 280 modern coccosphere types, or 190 if holococcoliths are eliminated. Moreover the number of recognized species appears to still be increasing rapidly, as indicated by a plot of cumulative number of species by date of description (text-fig, 2). From the curve shape it is difficult to avoid prediction that the number of coccolithophore types will continue to increase. Major causes of the increase in diversity have been detailed study of deep photic communities, use of high resolution SEMs to study smaller coccolithophores and, increasingly, more careful subdivision of known taxa. Of the 60 coccolithophores described in the last decade 20 are from the deep chlorophyll maximum or below, 55 are very small (coccoliths $<2.5 \mu \mathrm{m}$ ), and 25 are subdivisions of previously known taxa (notably in the genera Alisphaera, Polycrater, and Syracosphaera). There are almost certainly more small rare species to be described, especially from the deep photic zone and unquestionably much more subdivision of known taxa will be needed especially as molecular genetic data becomes available. It is quite possible that species numbers will rise to 500 or more. So we cannot give a simple answer to the question of how many species there are but only a range from 200 (the number of known forms excluding holococcoliths) to 500 (possible total diversity assuming a moderate degree of cryptic speciation).

\section{Preserved biodiversity in the Holocene}

In comparison to these estimates of a few hundred extant species, Bown et al. (2004) give an estimate of only 50 Holocene species. To elucidate this rather serious discrepancy, for each of the 280 coccosphere types estimates were made of abundance in the plankton and in the fossil record and of maximum coccolith size (see methods). From this data a size-frequency plot has been derived and subdivided according to abundance in the plankton (text-fig. 3A) and in the recent fossil record (text-fig 3B). In the fossil record our estimate is that there are 57 species with rare to common occurrences, this is essentially comparable to the estimate of Bown et al. (2004), with the slight increase being due to inclusion of pseudo-cryptic species in Coccolithus pelagicus and Calcidiscus leptoporus plus a few larger holococcoliths (the Helicosphaera and Syracosphaera pulchra holococcoliths) which have recently been shown to be relatively common although usually overlooked (Crudeli and Young 2003). Additionally, we recognize another 45 species which have very rare fossil records, i.e. have only been recorded a couple of times, typically in SEM studies of exceptionally preserved assemblages. The remaining 175 extant species/ coccolithophore types have to our knowledge never been observed in the fossil record. As indicated in text-figure 3B these missing taxa overwhelmingly produce small coccoliths, predominantly $<2.5 \mu \mathrm{m}$. Comparison with the plot of species in the plankton (text-fig. 3A) shows that these are also mostly very rare in the plankton. We conclude that there is a very large number of rare coccolithophores that produce small coccoliths, which are not represented in the fossil record. In text-figure 4 the size data for extant coccosphere types is broken down by taxonomic group. This shows that the dominant groups producing small coccoliths are holococcoliths, Syracosphaerales and the incertae sedis groups, especially the Alisphaeraceae and Papposphaeraceae.

Since these missing taxa are both rare and small it is difficult to be sure which factor is more important in controlling their fossil record. However it is noteworthy that among the larger coccoliths there are several taxa which are rare in the plankton but reliably present in the fossil record. Obvious examples include the Pontosphaera species (maximum lengths 8-14 $\mu \mathrm{m}$ ), Hayaster perplexa $(8 \mu \mathrm{m})$, Tetralithoides quadrilaminata $(8 \mu \mathrm{m})$ and the holococcolith Syracolithus schilleri $(4 \mu \mathrm{m})$. All of these are only found very sporadically in the plankton but, with careful scanning by light microscopy, specimens can be found in most Holocene samples. Conversely, relatively abundant taxa producing small coccoliths, such as Ophiaster or Calciopappus, have virtually no recorded fossil record. Obviously observation techniques are a major constraint, with light microscopy it is

\section{PLATE 3}

Polymorphism in other motile coccolithophores

1 Helicosphaera carteri showing varimorphism, the coccoliths surrounding the flagellar opening (top left) are larger and have more strongly developed wings than those on the rest of the coccosphere, but they do not differ in anyway from them structurally.

2 Acanthoica quattrospina showing body coccoliths without spines, long and short-spined circumflagellar coccoliths and antapical coccoliths. The circum flagellar coccoliths have similar bases to the body coccoliths but those of the antapical coccoliths are strongly modified (inset).
3 Gladiolithus flabellatus showing long tube coccoliths in upper part and disk-like "lepidoliths" in lower part.

4 Helladosphaera cornifera - a holococcolithophore showing circum-flagellar coccoliths with elevated bridges ("helladoliths"). N.B. This is possibly the holococcolith stage of Syracosphaera nodosa, see Cros et al. (2000).

5 Sphaerocalyptra sp. 1 of Cros and Fortuno 2002 - a holococcolithophore showing unusually strong dimorphism, circum flagellar coccoliths with flat bases and tall spines. 


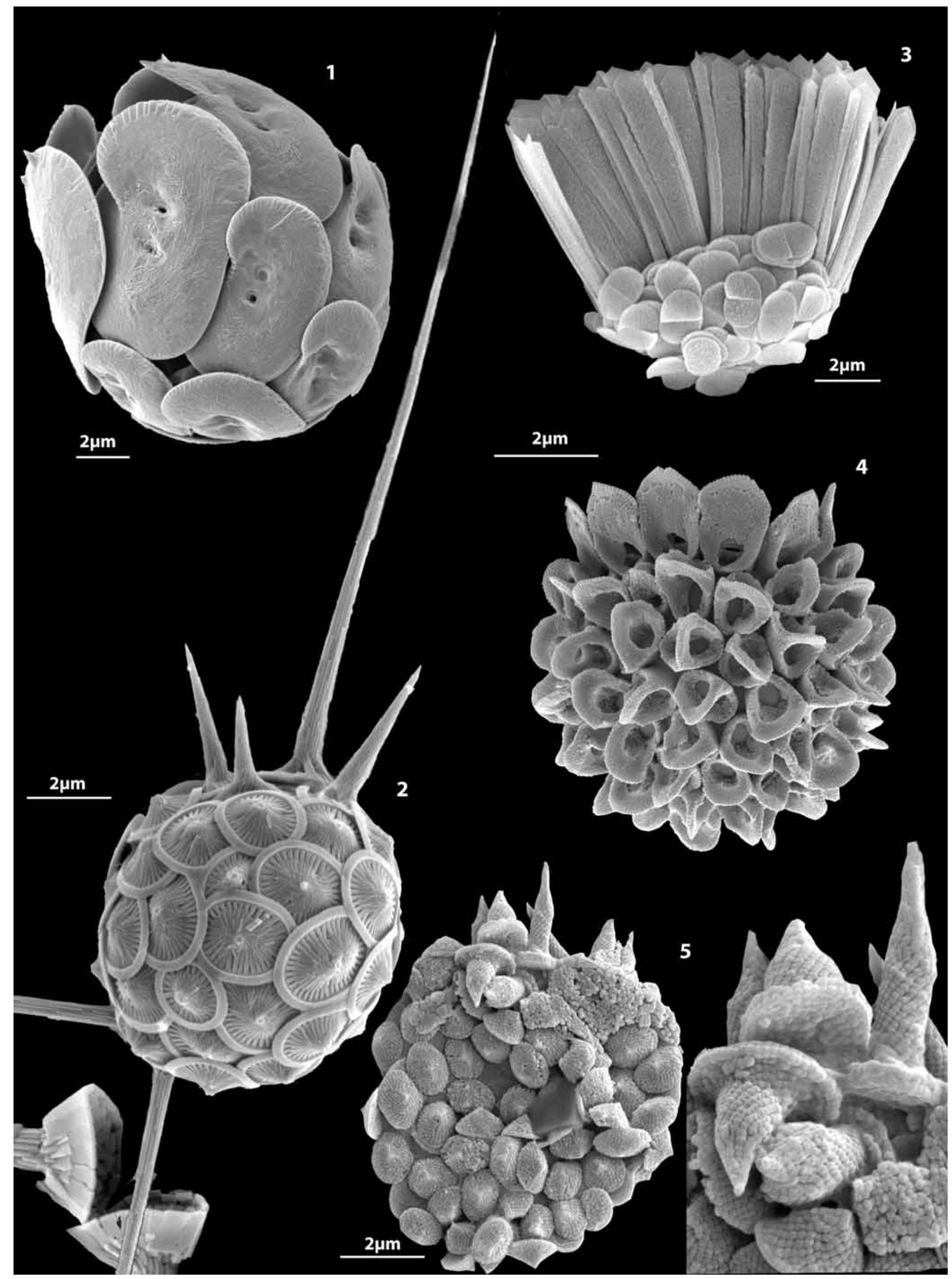


difficult to observe coccoliths smaller than about $2.5 \mu \mathrm{m}$ and only the most distinctive species can be observed. Conversely with electron microscopy it is much less practical to scan very large numbers of specimens for rare species. Preservation is also, however, a major factor. Cumulatively the numerous small rare species might be expected to contribute a significant number of small coccoliths to fossil assemblages which could be seen even if they could not easily be identified. However, with normal preservation there are usually rather few such coccoliths. Detailed study of sediment trap and Holocene samples indicates that most such species are lost to dissolution in the water column (Andruleit et al. 2004, Baumann et al. in press). Selective dissolution of small coccoliths is to be expected since they are formed of small and so less stable crystals. Much of the loss occurs in the water column but it will continue in the sediment during diagenesis.

Given the very large number of species producing small rare coccoliths and the likelihood that they are predominantly lost due to dissolution in the water column and during diagenesis, we may predict that under exceptional preservation conditions, for example shelf deposits with very low diagenesis, a much higher diversity of fossil coccoliths will be available to study, although electron microscopy will be needed. There are examples of such studies on Mesozoic coccoliths (e.g. Goy 1981; Thomsen 1989) but rather fewer in the Cenozoic, especially the Neogene. Study of sapropel sediments from the Eastern Mediterranean (Müller et al. 1974; Crudeli and Young 2003) has provided an example of how the number of observed coccolith species can be much higher in exceptionally preserved sediments.

For interpretation of fossil diversity data this size-preservation effect has various implications. Obviously a basic implication is that all estimates of paleo-diversity are likely to be significant underestimates of total diversity. Further there is an obvious possibility for monographic effects, i.e. a distortion of diversity data for particular time periods through detailed descriptions of exceptionally preserved biotas. More subtly there is the possibility that changes in coccolith size frequency through time may produce changes in observed diversity independently of any change in actual diversity. That is, if as a result of changing ecological conditions average coccolith size was reduced, then, without any change in true diversity, the number of observed coccolith species in the fossil record would decrease. Very little data has been compiled on changes in average coccolith size through the geological record but most biostratigraphers would agree that there are significant changes, with for example a significant size reduction during the Pliocene and Pleistocene. Clearly it would be useful to analyse diversity change and size change in parallel.

\section{DISCUSSION AND CONCLUSIONS}

Coccolithophores are probably one of the best studied groups of protists and have their taxonomy better documented than almost any other group, nonetheless new species continue to be discovered at a considerable rate. Moreover, there is increasing uncertainty about how reliable taxonomic concepts are in the light of evidence of cryptic speciation. As a result, the number of extant coccolithophores cannot be precisely stated but only estimated as between 200 and 500. In the fossil record, even of the Holocene, less than half of the known diversity has been recorded and less than a quarter of species have sufficiently reliable fossil records to enable their geological ranges to be estimated meaningfully. Given this, attempting to use enumeration of fossil coccolith species to calculate the "true" diversity of past assemblages is plainly an impossible exercise. This consideration applies equally to virtually any paleontological diversity data, with the possible exception of planktonic foraminifera. Thus, essentially paleontologists use fossil diversity data as time series information which provides a proxy of original biodiversity, and so an indication of biodiversity dynamics (Smith 2003). Given this, the prime consideration for analysis of potentially distorting influences is whether they are likely to change through time.

Life-cycle combinations are biologically fascinating and are greatly changing our understanding of coccolithophore ecology, but, as discussed, the apparent similarity of cycles across haptophyte diversity suggests that they have not evolved greatly through geological time. The prime exception is that the relative importance of holococcolith producing families vs. other families may have changed, especially between the Mesozoic and Cenozoic. However, this would be a very long term change and would be unlikely to affect patterns of diversity gain and loss on the time scales usually looked at in terms of paleobiodiversity change (ca. $10 \mathrm{Ma}$ ).

Polymorphism is potentially a significant distorting influence but again it shows a rather strong taxonomic linkage and is unlikely to change rapidly through time distorting diversity patterns on relevant timescales, although as with life-cycles it

\section{PLATE 4}

Polymorphism in non-motile coccolithophores

1 Rhabdosphaera clavigera - dimorphic with an inner layer of spine bearing coccoliths and an outer layer of coccoliths without spines.

2 Scyphosphaera apsteinii - dimorphic with elevated equatorial coccoliths (lopadoliths) and almost flat body coccoliths.
3 Umbellosphaera tenuis - dimorphic or varimorphic, upper image complete coccosphere, lower image (same scale) broken specimen showing the very great range of coccolith size and relative rim width, see Kleijne (1993) for an extended discussion. 


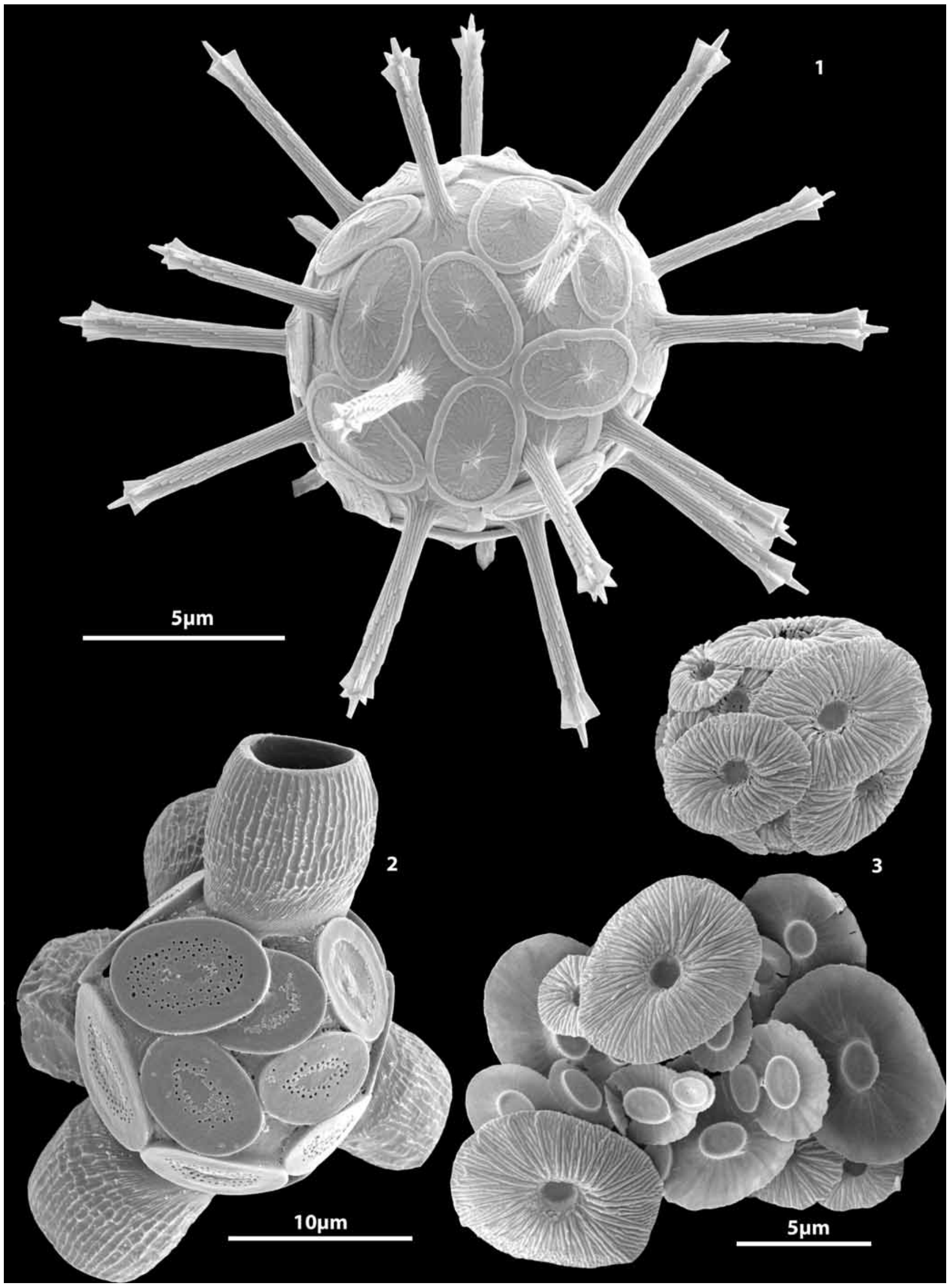


might affect very long timescale trends. For instance, comparison of Mesozoic and Cenozoic diversity could be compromised if there was significant undetected polymorphism in the Mesozoic. More fundamentally at least for the Cenozoic the main groups which show polymorphism, the Syracosphaeraceae, Papposphaeraceae and Rhabdosphaeraceae have very low preservation potential and thus have minimal impact on the fossil biodiversity data.

Pseudo-cryptic speciation and species-level taxonomic concepts are undoubtedly a factor which seriously decrease our ability to make consistent estimates of fossil diversity even for the subset of preserved species. However, this may be argued to be a factor which should not change through time and so should not distort patterns of biodiversity dynamics.

Finally there is the problem of preservation potential. As outlined this is a very real problem for coccolithophores, since only a small sub-set of total diversity is preserved, leaving a very high diversity of small rare coccoliths with virtually no fossil record. This does mean that nannofossil biodiversity estimates are vulnerable to false signals due to (1) Variation in abundance of strata with ideal preservation conditions (e.g laminated shelf sediments with low diagenesis), in which a higher proportion of species are likely to be preserved. (2) Monographic effects from variable intensity of research on sediments of this type in different time intervals. There are for instance very few detailed SEM studies of really well-preserved Neogene nannofossil assemblages and such studies would very probably significantly increase the number of described Neogene species. (3) Potentially ecological conditions may at times have favoured larger coccoliths and this could cause an apparent diversity increase independent of any actual diversity increase. At least in the Cenozoic this would also probably lead to an increased representation of groups such as the Rhabdosphaeraceae and holococcoliths which are polymorphic, thus increasing the biasing effect. Preservation-related factors are liable to cause real problems for coccolithophore paleobiodiversity estimates and should be particularly carefully considered in interpretation of such data.

\section{ACKNOWLEDGMENTS}

The collaboration and research underpinning this review was funded by the CODENET EU-TMR FP5 Network project, and by the EREUPT NSF Biodiversity project. We are grateful to many colleagues in these projects for illuminating discussions and to Maria Triantaphyllou and Luc Beaufort for careful reviews.

\section{REFERENCES}

ALCOBER, J., and JORDAN, R.W., 1997. An interesting association between Neosphaera coccolithomorpha and Ceratolithus cristatus (Haptophyta). European Journal of Phycology, 32: 91-93.

ANDRULEIT, H., ROGALLA, U., and STÄGER, S., 2004. From living communities to fossil assemblages: origin and fate of coccolithophores in the northern Arabian Sea. In: M. Triantaphylou, Ed., Advances in the biology, ecology and taxonomy of extant calcareous nannoplankton. Micropaleontology, 50(supplement 1): $5-21$.

BAUMANN, K.-H., ANDRULEIT, H., BÖCKEL, B., GEISEN, M., and KINKEL, H., in press. The significance of extant coccolithophores as indicators of ocean water masses, surface water temperature, and paleoproductivity: a review. Palaeontologische Zeitschrift, 79 (1).

BAUMANN, K.-H., and SPRENGEL, C., 2000. Morphological variations of selected coccolith species in a sediment trap north of the $\mathrm{Ca}$ nary Islands. Journal of Nannoplankton Research, 22(3): 185-193.

BILLARD, C., 1994. Life cycles. In: J.C. Green, and B.S.C. Leadbeater, Eds., The Haptophyte Algae, 51, p. 167-186. Oxford: Clarendon Press.

BILLARD, C., and INOUYE, I., 2004. What's new in coccolithophore biology? In H.R. Thierstein, and J.R. Young, Eds., Coccolithophores - From molecular processes to global impact. Springer, 1-29.

BLEIJSWIJK, J.V., WAL, P.V.D., KEMPERS, R., and VELDHUIS, M.J.W., 1991. Distribution of two types of Emiliania huxleyi (Prymnesiophyceae) in the northeast Atlantic region as determined by immunofluorescence and coccolith morphology. Journal of Phycology, 27: 566-570.

\section{PLATE 5}

Calcidiscus leptoporus (sensu lato) morphotypes

1-3 large morphotype/Calcidiscus quadriperforatus

46 intermediate morphotype/Calcidiscus leptoporus (sensu stricto)
7-10 small morphotype. Images 1-10 all the same scale.

11-13 coccolith details of the large (11), intermediate (12) and small (13) morphotypes, scale bars 1 micron.

As these images show, coccolith size separates the morphotypes better than coccosphere size, but even so the "large" and "intermediate" morphotypes overlap in coccolith size. The "large" morphotype, however, is reliably distinguished by the zone of obscured sutures surrounding the central area, whilst the small morphotype has more angular sutures. Culture studies, life-cycle data (associated holococcolith phases) and molecular genetics have proven that the large and intermediate morphotypes are well-differentiated species, and it is predicted that this will also be the case for the small morphotype. 


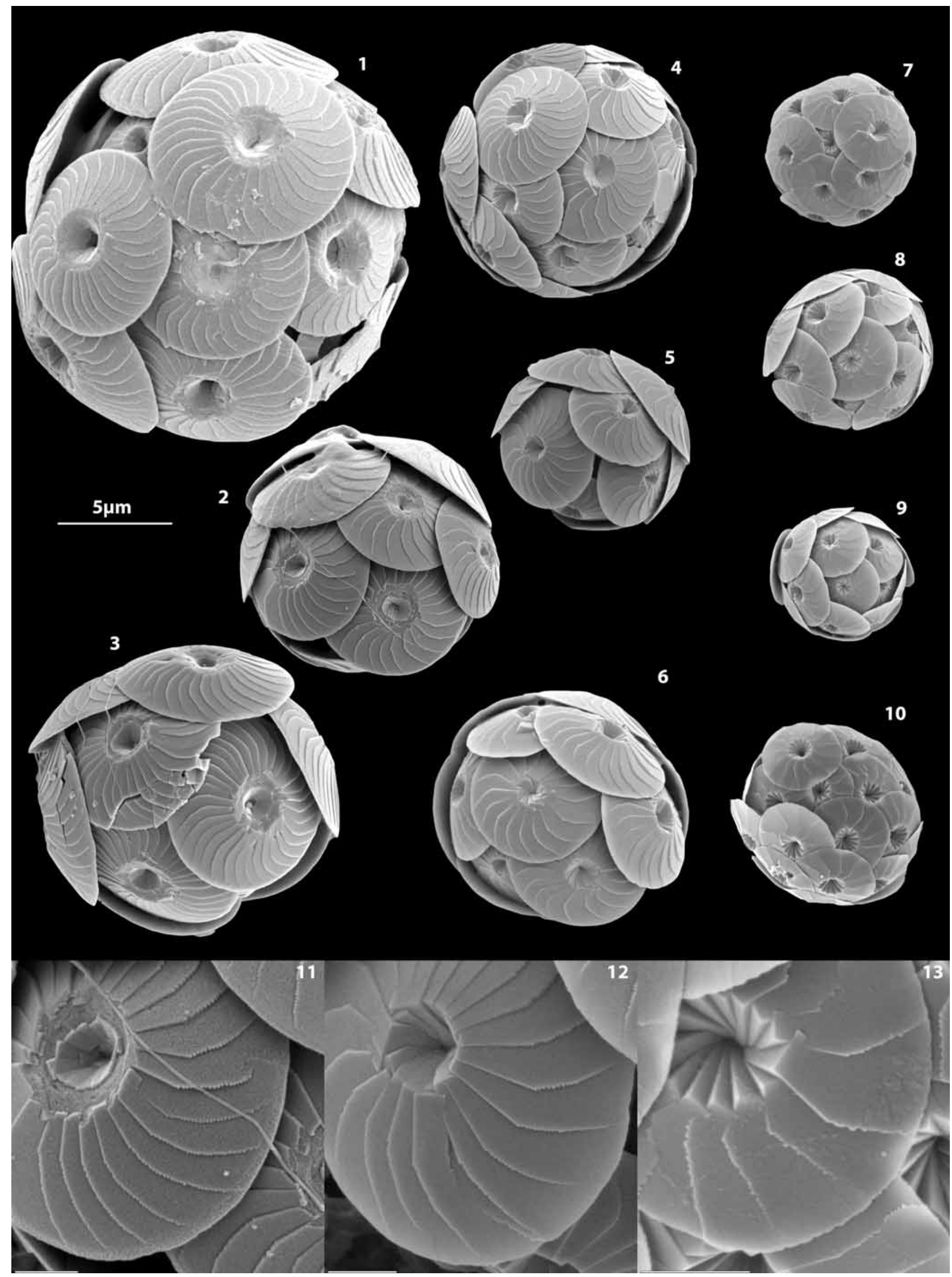


BOLLMANN, J., 1997. Morphology and biogeography of Gephyrocapsa coccoliths in Holocene sediments. Marine Micropaleontology, 29: 319-350.

BOLLMANN, J., HENDERIKS, J., and BRABEC, B., 2002. Calibration of Gephyrocapsa coccolith abundance in Holocene sediments for paleotemperature assessment. Paleoceanography, 17/3, article 7, p.1-9.

BOWN, P.R., LEES, J.A., and YOUNG, J.R., in 2004. Calcareous nannoplankton evolution and diversity through time. In H.R. Thierstein, and J.R. Young, Eds., Coccolithophores - From molecular processes to global impact. Springer, p. 481-508.

CORTÉS, M.Y., 2000. Further evidence for the heterococcolith-holococcolith combination Calcidiscus leptoporus-Crystallolithus rigidus. Marine Micropaleontology, 39(1-4): 35-37.

CORTÉS, M.Y., and BOLLMANN, J., 2002. A new combination coccosphere of the heterococcolith species Coronosphaera mediterranea and the holococcolith species Calyptrolithophora hasleana. European Journal of Phycology, 37: 145-146.

COVINGTON, J.M., 1985. New morphologic information on Cretaceous nannofossils from the Niobrara Formation (Upper Cretaceous) of Kansas. Geology, 13(10): 683-686.

CROS, L., 2000. Variety of exothecal coccoliths of Syracosphaera. Journal of Nannoplankton Research, 22(1): 41-51.

CROS, L., and FORTUÑO, J.-M., 2002. Atlas of Nothwestern Mediterranean Coccolithophores. Scientia Marina, 66: 186.

CROS, L., KLEIJNE, A., ZELTNER, A., BILLARD, C., and YOUNG, J.R., 2000. New examples of holococcolith-heterococcolith combination coccospheres and their implications for coccolithophorid biology. Marine Micropaleontology, 39(1-4): 1-34.

CRUDELI, D., and YOUNG, J.R., 2003. SEM-LM study of holococcoliths preserved in Eastern Mediterranean sediments (Holocene/Late Pleistocene). Journal of Nannoplankton Research, 25(1): 39-50.

DE VARGAS, C., SÁEZ, A.G., MEDLIN, L.K., and THIERSTEIN, H.R., 2004. Super-species in the calcareous plankton. In H.R. Thierstein, and J.R. Young, Eds., Coccolithophores - From molecular processes to global impact. Springer, pp 271-298.

EDVARDSEN, B., EIKREM, W., GREEN, J.C., ANDERSEN, R.A., YEO MOON-VAN DER STAAY, S., and MEDLIN, L.K., 2000. Phylogenetic reconstructions of the Haptophyta inferred from $18 \mathrm{~S}$ ribosomal DNA sequences and available morphological data. Phycologia, 39(1): 19-35.

FINDLAY, C.S., and GIRAUDEAU, J., 2001. Extant calcareous nannoplankton in the Australian sector of the Southern Ocean (austral summers 1994 and 1995). Marine Micropaleontology, 40(4): 417-439.

FRESNEL, J., 1994. A heteromorphic life cycle in two coastal coccolithophorids, Hymenomonas lacuna and Hymenomonas coronata (Prymnesiophyceae). Canadian Journal of Botany, 72: 1455-1462.

FUJIWARA, S., TSUZUKI, M., KAWACHI, M., MINAKA, N., and INOUYE, I., 2001. Molecular phylogeny of the haptophyta based on the $r b c \mathrm{~L}$ gene and sequence variation in the spacer region of the RUBISCO operon. Journal of Phycology, 37: 121-129.

GAYRAL, P., and FRESNEL, J., 1983. Description, sexualité et cycle de développment d'une nouvelle coccolithophoracée
(Prymnesiophyceae): Pleurochrysis pseudoroscoffensis sp. nov. Protistologica, 19(2): 245-261.

GEISEN, M., BILlARD, C., BROERSE, A.T.C., CROS, L., PROBERT, I., and YOUNG, J.R., 2002. Life-cycle associations involving pairs of holococcolithophorid species: intraspecific variation or cryptic speciation? European Journal of Phycology, 37: 531-550.

GEISEN, M., YOUNG, J.R., PROBERT, I., SÁEZ, A.G., BAUMANN, K.-H., BOLLMANN, J., CROS, L., DEVARGAS, C., MEDLIN, L.K., and SPRENGEL, C., 2004. Species level variation in coccolithophores. In: H.R. Thierstein, and J.R. Young, Eds., Coccolithophores - From molecular processes to global impact. Springer, p. 327-366.

GOY, G., 1981. Nannofossiles calcaires des schistes carbon (Toarcien Inferieur) du Bassin de Paris. Doc. de la RCP 459, Nature et genese des facies confines, (Editions du BRGM), 1: 86.

GREEN, J.C., COURSE, P.A., and TARRAN, G.A., 1996. The life-cycle of Emiliania huxleyi: A brief review and a study of relative ploidy levels analysed by flow cytometry. Journal of Marine Systems, 9: $33-44$

GREEN, J.C., PERCH-NIELSEN, K., and WESTBROEK, P., 1989. Phylum Prymnesiophyta. In: L. Margulis, J. Corliss, M. Melkoniam, and D. Chapman, Eds., Handbook of Protoctista, 1, p. 293-317. Jones and Bartlett, Boston.

HOUDAN, A., BILlARD, C., MARIE, D., NOT, F., SÁEZ, A.G., YOUNG, J.R., and PROBERT, I., 2004. Flow cytometric analysis of relative ploidy levels in holococcolithophore-heterococcolithophore (Haptophyta) life cycles. Systematics and Biodiversity, 1(4). 453-465.

IGLESIAS-RODRÍGUEZ, M.D., SÁEZ, A.G., GROBEN, R., EDWARDS, K.J., BATLEY, J., MEDLIN, L.K., and HAYES, P.K., 2002. Polymorphic microsatellite loci in global populations of the marine coccolithophorid Emiliania huxleyi. Molecular Ecology Notes, 2: 495-497.

INOUYE, I., and PIENAAR, R.N., 1984. New observations on the coccolithophorid Umbilicosphaera sibogae var. foliosa (Prymnesiophyceae) with reference to cell covering, cell structure and flagellar apparatus. British Phycological Journal, 19: 357-369.

1988. Light and electron microscope observations of the type species of Syracosphaera, S. pulchra (Prymnesiophyceae). British Phycological Journal, 23: 205-217.

JORDAN, R.W., CROS, L., and YOUNG, J.R., 2004. A revised classification scheme for living Haptophytes. In, M. Triantaphylou (ed.) Advances in the biology, ecology and taxonomy of extant calcareous nannoplankton. Micropaleontology, 50(suppl. 1): 55-79.

JORDAN, R.W., and YOUNG, J.R., 1990. Proposed changes to the classification system of living Coccolithophorids. International Nannoplankton Association Newsletter, 1(12): 15-18.

KAMPTNER, E., 1941. Die Coccolithineen der Südwestküste von Istrien. Annalen des Naturhistorischen Museums in Wien, 51: 54-149.

KLAVENESS, D., 1972. Coccolithus huxleyi (Lohmann) Kamptner. II. - The flagellate cell, aberrant cell types, vegetative propagation and life cycles. British Phycological Journal, 7: 309-318.

KLEIJNE, A., 1991. Holococcolithophorids from the Indian Ocean, Red Sea, Mediterranean Sea and North Atlantic Ocean. Marine Micropaleontology, 17: 1-76. 
1993. Morphology, Taxonomy and distribution of extant coccolithophorids (Calcareous nannoplankton). 321 p. Drukkerij FEBO B.V., Katwijk.

KNAPPERTSBUSCH, M., 1997. Morphologic variability of the coccolithophorid Calcidiscus leptoporus in the plankton, surface sediments and from the Early Pleistocene. Marine Micropaleontology, 30: 293-317.

LAMBERT, B., 1986. La notion d'espèce chez le genre Braarudosphaera Deflandre, 1947: mythe et réalité. Revue de Micropaleontologie, 28(4): 255-264.

_- , 1987. Nannofossiles calcaires de l'Albien supérieur et du Vraconnien du Cameroun méridional. Cahiers de Micropaléontologie, 2(2): 33-60.

1993. Nannofossiles calcaires de l'Albien supérieur et du Vraconnien du Cameroun méridional (Deuxième Partie). Cahiers de Micropaleontologie, 8(2): 183-225.

LECAL-SCHLAUDER, J., 1961. Anomalies dans la composition des coques de flagelles calcaires. Bulletin de la Société d'Histoire Naturelle de l'Afrique du Nord, 52: 63-66.

LOHMANN, H., 1902. Die Coccolithophoridae, eine Monographie der Coccolithen bildenden Flagellaten, zugleich ein Beitrag zur Kenntnis des Mittelmeerauftriebs. Archiv für Protistenkunde, 1: 89-165.

MAI, H., von SALIS PERCH-NIELSEN, K., WILLEMS, H. and ROMEIN, T., 1997. Fossil coccospheres from the K/T boundary section from Geulhemmerberg, The Netherlands. Micropaleontology, 43(3): 281-302.

MARKALI, J., and PAASCHE, E., 1955. On two species of Umbellosphaera, a new marine coccolithophorid genus. Nytt Magasin for Botanikk, 4: 95-100.

MEDLIN, L.K., BARKER, G.L.A., GREEN, J.C., HAYES, D.E., MARIE, D., WRIEDEN, S., and VAULOT, D., 1996. Genetic characterization of Emiliania huxleyi (Haptophyta). Journal of Marine Systems, 9: 13-32.

MÜLLER, C., BLANC VERNET, L., CHAMLEY, H., and FROGET, C., 1974. Les coccolithophorides d'une carotte Méditerranéenne. Comparaison paléoclimatologique avec les foraminifères, les ptéropodes et les argiles. Tethys, 6(4): 805-828.

NISHIDA, S., 1979. Atlas of Pacific Nannoplanktons. News of Osaka Micropaleontologists Special Paper, 3: 1-31.

NOËL, M.-H., KAWACHI, M., and INOUYE, I., 2004. Induced dimorphic life cycle of a coccolithophorid, Calyptrosphaera sphaeroidea. Journal of Phycology, 40(1): 112-129.

NORRIS, R.E., 1965. Living cells of Ceratolithus cristatus (Coccolithophorineae). Archiv für Protistenkunde, 108: 19-21.

OKADA, H., and MCINTYRE, A., 1977. Modern coccolithophores of the Pacific and North Atlantic Oceans. Micropaleontology, 23(1): $1-55$.

PAASCHE, E., 2002. A review of the coccolithophorid Emiliania huxleyi (Prymnesiophyceae), with particular reference to growth, coccolith formation, and calcification-photosynthesis interactions. Phycologia, 40(6): 503-529.

PARENTE, A., CACHAO, M., BAUMANN, K-H., de ABREU, L., FERREIR, J. 2004 Morphometry of Coccolithus pelagicus s.l. (Coccolithophore, Haptophyta) from offshore Portugal, during the last 200 kyr. In, M. Triantaphylou (ed.) Advances in the biology, ecology and taxonomy of extant calcareous nannoplankton. Micropaleontology, 50 suppl. 1, 107-120.

PARKE, M., and ADAMS, I., 1960. The motile (Crystallolithus hyalinus Gaarder and Markali) and non-motile phases in the life history of Coccolithus pelagicus (Wallich) Schiller. Journal of the Marine Biological Association of the United Kingdom, 39: 263-274.

PEPERZAK, L., COLIJN, F., VRIELING, E.G., GIESKES, W.W.C., and PEETERS, J.C.H., 2000. Observations of flagellates in colonies of Phaeocystis globosa (Prymnesiophyceae); a hypothesis for their position in the life cycle. Journal of Plankton Research, 22(12): 2181-2203.

QUINN, P., SÁEZ, A.G., BAUMANN, K.-H., STEEL, B.A., SPRENGEL, C., and MEDLIN, L.K., 2004. Coccolithophorid biodiversity: Evidence from the cosmopolitan species Calcidiscus leptoporus. In: H.R. Thierstein, and J.R. Young, Eds., Coccolithophores - From molecular processes to global impact. Springer, 299-326.

QUINN, P., THIERSTEIN, H.R., BRAND, L.E., and WINTER, A., 2003. Experimental evidence for the species character of Calcidiscus leptoporus morphotypes. Journal of Paleontology, 77(5): 825-830.

RAYNS, D.G., 1962. Alternation of generations in a coccolithophorid, Cricosphaera carterae (Braarud and Fragerl.) Braarud. Journal of the Marine Biological Association of the United Kingdom, 42: 481-484.

RENAUD, S., and KLAAS, C., 2001. Seasonal variations in the morphology of the coccolithophore Calcidiscus leptoporus off Bermuda (N. Atlantic). Journal of Plankton Research, 23(8): 779-795.

ROWSON, J.D., LEADBEATER, B.S.C., and GREEN, J.C., 1986. Calcium carbonate deposition in the motile (Crystallolithus) phase of Coccolithus pelagicus (Prymnesiophyceae). British Phycological Journal, 21: 359-370.

SÁEZ, A.G., PROBERT, I., GEISEN, M., QUINN, P., YOUNG, J.R., and MEDLIN, L.K., 2003. Pseudo-cryptic speciation in coccolithophores. Proceedings of the National Academy of Science of the United States of America, 100(12): 7163-7168.

SÁEZ, A.G., PROBERT, I., YOUNG, J.R., and MEDLIN, L.K., 2004. A review of the phylogeny of the Haptophyta. In H.R. Thierstein, and J.R. Young, (eds), Coccolithophores - from molecular processes to global impact. Springer, 251-270

SAMTLEBEN, C., and SCHRÖDER, A., 1992. Living coccolithophore communities in the Norwegian-Greenland Sea and their record in sediments. Marine Micropaleontology, 19: 333-354.

SAUGESTAD, A.H., and HEIMDAL, B.R., 2002. Light microscope studies on coccolithophorids from the western Mediterranean Sea, with notes on combination cells of Daktylethra pirus and Syracosphaera pulchra. Plant biosystems, 136(1): 3-28.

SCHWARZ, E., 1932. Beiträge zur Entwicklungsgeschichte der Protophyten. IX. Der Formwechsel von Ochrosphaera neapolitana. Archiv für Protistenkunde, 77: 434-462.

SMITH, A.B., 2003. Getting the measure of diversity. Paleobiology, 29(1): 34 .

SPRENGEL, C., and YOUNG, J.R., 2000. First direct documentation of associations of Ceratolithus cristatus ceratoliths, hoop-coccoliths and Neosphaera coccolithomorpha planoliths. Marine Micropaleontology, 39(1-4): 39-41.

STEEL, B.A., 2001. Physiology, growth and morphometry of selected extant coccolithophorids, with particular reference to Calcidiscus 
leptoporus (Murray and Blackman, 1889) Loeblich and Tappan 1987. Earth Sciences, Unpublished MSc Thesis, University College London, 83p.

SYM, S., and KAWACHI, M., 2000. Ultrastructure of Calyptrosphaera radiata, sp. nov. (Prymnesiophyceae, Haptophyta). European Journal of Phycology, 35: 283-293.

THOMSEN, E., 1989. Seasonal variation in boreal Early Cretaceous calcareous nannofossils. Marine Micropaleontology, 15(1-2): 123-152.

THOMSEN, H.A., OSTERGAARD, J.B., and HANSEN, L.E., 1991. Heteromorphic life histories in Arctic coccolithophorids (Prymnesiophyceae). Journal of Phycology, 27: 634-642.

TRIANTAPHYLLOU, M., and DIMIZA, M.D., 2003. Verification of the Algirosphaera robusta - Sphaerocalyptra quadridentata (coccolithophores) life-cycle association. Journal of Micropalaeontology, 22(1): 107-111.

TRIANTAPHYLLOU, M., DIMIZA, M.D., and DERMITZAKIS, M., 2003. A new coccolithophore life-cycle association: Syracosphaera halldalii (Heterococcolithophore) and Calyptrolithina divergens var. tuberosa (Holococcolithophore). Gaia, 11: 77-80.

- _ 2004. A new coccolithophore life-cycle association: Syracosphaera halldalii (Heterococcolithophore) and Calyptrolithina divergens var. tuberosa (Holococcolithophore). In: M. Triantaphylou, Ed., Advances in the biology, ecology and taxonomy of extant calcareous nannoplankton. Micropaleontology, 50(suppl. 1): $121-126$

VALERO, M., RICHERD, S., PERROT, V., and DESTOMBE, C., 1992. Evolution of alternation of haploid and diploid phases in life cycles. Trends in Ecology and Evolution, 7(1): 25-29.

VAULOT, D., BIRRIEN, J.-L., MARIE, D., CASOTTI, R., VELDHUIS, M., KRAAY, G., and CHRÉTIENNOT-DINET, M.-J., 1994. Morphology, ploidy, pigment composition, and genome size of cultured strains of Phaeocystis (Prymnesiophyceae). Journal of Phycology, 30: 1022-1035.

WALLICH, G.C., 1877. Observations on the coccosphere. Annals and Magazine of Natural History, 19: 342-350.
WINTER, A., and SIESSER, W.G., 1994. Coccolithophores. 242 pp. Cambridge: Cambridge University Press.

YOUNG J.R., TEALE C.T., and BOWN P.R., 1986; Revision of the stratigraphy of the Longobucco Group (Liassic, southern Italy); based on new data from nannofossils and ammonites. Eclogae Geologae Helvetiae, 79, 117-135.

YOUNG, J.R., BOWN, P.R. and BURNETT, J.A. 1994. Palaeontological perspectives. In: J. C. Green and B. S. C. Leadbeater, Eds., The Haptophyte Algae. Systematics Association Special Volume, 51: 379-392.

YOUNG, J.R., DAVIS, S.A., BOWN, P.R., and MANN, S., 1999. Coccolith ultrastructure and biomineralisation. Journal of Structural Biology, 126: 195-215.

YOUNG, J.R., GEISEN, M., CROS, L., KLEIJNE, A., PROBERT, I., and OSTERGAARD, J.B., 2003. A guide to extant coccolithophore taxonomy. Journal of Nannoplankton Research, Special Issue, 1: $1-132$.

YOUNG, J. R. and HENRIKSEN K, 2003. Biomineralization within vesicles: the calcite of coccoliths. In: Dove P.M., De Yoreo J. J., Weiner S., Eds., Biomineralisation. Reviews in Mineralogy and Geochemistry, 54: 189-215.

YOUNG J. R., HENRIKSEN K., PROBERT I., 2004. Structure and morphogenesis of the coccoliths of the CODENET species. In: Thierstein H. R. and Young J. R., Eds., Coccolithophores from cellular process to global impact. Springer Verlag, pp. 191-216.

YOUNG, J.R., JORDAN, R.W., and CROS, L., 1998. Notes on nannoplankton systematics and life-cycles - Ceratolithus cristatus, Neosphaera coccolithomorpha and Umbilicosphaera sibogae. Journal of Nannoplankton Research, 20(2): 89-99.

YOUNG, J.R., and WESTBROEK, P., 1991. Genotypic variation in the coccolithophorid species Emiliania huxleyi. Marine Micropaleontology, 18: 5-23.

ZIVERI, P., BAUMANN, K.-H., BOLLMANN, J., and YOUNG, J.R., 2004. Present day coccolithophore biogeography of the Atlantic Ocean. In: H.R. Thierstein, and J.R. Young, Eds., Coccolithophores From molecular processes to global impact. Springer, pp. 403-428. 